\title{
4 \\ Opportunities for freedom and for domination
}

\section{Key propositions}

- Anomie Américaine is not a substitute for anomie ancienne; it complements it.

- Within anomie Américaine, Merton, Cloward, Ohlin, Cohen, Messner and Rosenfeld add decisively to an institutional anomie theory of a plurality of institutions that temper domination.

- The evidence grows increasingly suggestive that a rich plurality of institutions that temper the hegemony of economic institutions, that temper commodification, can reduce crime and increase freedom.

- When legitimate opportunities and opportunities for freedom are open, and when illegitimate opportunities and opportunities to dominate others are closed, crime is reduced and freedom is enhanced.

- Domination is the more fertile concept than inequality for explaining violence, with militarised domination and criminalised domination of governments and markets particularly critical. Yet struggles against domination and discrimination must be contextually attuned and responsive to what are subjectively salient inequalities.

- Local micro-dominations (for example, between landlords and peasants) can be more important in explaining violence than more macro or more national inequalities. Because it is hard to predict which levels of domination will fuel raging fires of subjective oppression and violence, and which will not, societies do well to aim at tempering all kinds of domination. 
- It is common for multicollinearity to produce the result that inequality explains crime, but poverty or racial discrimination does not; or that poverty explains crime, but inequality does not; or that child mortality but none of these other measures explains crime. Often what is true in individual or ecological data is not true in time-series studies, or at least not true in time-series with short lags. We do best to read this literature with a spirit of openness to domination effects that are socially constructed as oppressive at different times, places and levels of analysis in different ways with different lags. We must be wary of a selective positivism that, after failing to find a particular linear effect, empowers analysis paralysis over inequality effects. Likewise, we must be wary of selectivity in attention to the data by social democrats like me on questions of inequality.

- Racial, gender, religious and caste discrimination and discrimination against children who perform poorly at school count among the recurrent contributors to domination and crime. Empirically, discrimination that is sanctioned by the state poses the gravest danger to societies.

- Reducing national inequality on its own is less likely to have an impact than an integrated struggle against local, national and global inequalities of the kinds that the oppressed perceive as most destructive and humiliating. This is because intersectional domination explains violence better than a thin conception of inequality measured by a national Gini coefficient. The integrated social justice strategy required involves making power accountable at all levels and tackling domination and humiliation at the level of the school, the local community, the refugee camp, the bank, at the national level and the level of global imaginaries and global institutions. Most importantly, these strands of a web of justice, peace and nondomination must be joined up. That is difficult work requiring patience for weavers of a fabric of peace and nondomination.

- Redemptive schooling can contribute to a less anomic society by assisting every citizen along the journey of discovering valuable ways they can excel.

- Societies and schools that institutionalise failure, and societies afflicted with a commodified and militarised vision of what success and failure mean, suffer high crime rates and domination. 
- Inequality and poverty relate differently to crime and war and along different pathways. Because war tends to cascade to crime and crime to war, a helpful strategy for indirect prevention of crime-war cascades is to reduce extremes of poverty and inequality, particularly those most salient to the subjective sense of domination of a people in an incendiary situation of oppression.

- Explaining crime-war as a cascade can be attractive to the point of conceiving of violence and crime as variables that evolve together, collectively: from world wars to international wars, civil wars, 'smalltown wars', drug cartel wars, street gang wars, tiny terrorist cells, and mass and individual shootings by individuals. There are also important distinctions among these types of violence. The criminalisation of states and markets is so responsive to organised criminality and militarisation that crime and war cannot and should not be completely separated in historiography and in violence research.

- Domination grows in radically unequal societies. The rich tend to enjoy unaccountable power, while the poor can be desperate in their powerlessness. A narrow elite can put in place extractive political institutions that concentrate power in their hands; they disable constraints on the exercise of that power. Therefore, no topic is more critical for criminology than understanding how states and markets become criminalised.

- The times and places where women are more dominated tend to suffer more war, more crime-particularly sexual assault and violence against women-and less freedom. This is not because feminised armies cascade wars that cascade to postwar sexual assault and violence by female veterans. Feminised armies are exceptionally rare; Nepal is the only case where female fighters approached a majority at the core of a post-Cold War conflict. There is no feminist Frantz Fanon espousing the cleansing power of violence against male oppressors. Understanding exceptions is important to macrocriminological method. It is notable that pacified postwar Nepal achieved more major feminist constitutional transformations than any other society, postwar or without war, and a female Maoist general who became president. Like Nepal, the genocide against Yazidis in Iraq was started by men but finished with women playing prominent roles in another instructive and liberating exception. 
- It isimportant to understand in a Durkheimian way that industrialisation contributed to anomie and crime, as did deindustrialisation (see also Chapter 11). This complements the understanding we gain from Mertonian anomie.

- Durkheim, Messner and Rosenfeld were astute to see that welltempered institutions can temper appetites. They temper dangerous ambitions for narcissistic acquisitiveness. Plural institutions can shape aspirations for a humble pride that eschews vaunting pride.

- Commodification-market values that reduce all other values to their worth in markets-is a danger to freedom and to the tempering of crime.

- Militarisation-martial values that colonise other institutions, reducing other values to their worth for making the state great to dominate other peoples, or making the faith great to dominate other faiths - is a danger to freedom and to the tempering of crime.

\section{American and North Atlantic anomie}

The previous chapter was about anomie of an ancient and more Durkheimian kind. This chapter goes to anomie Américaine, following a trajectory that reads the most critical contributions as coming from Robert K. Merton, Richard Cloward and Lloyd Ohlin, Albert Cohen, and Steven Messner and Richard Rosenfeld. The decisive turning point was Merton, who came first along the journey towards what has come to be called institutional anomie theory. I cling to my attraction to anomie ancienne because of the possibilities revealed in the previous chapter for opening up the widest historical vistas of massive movements of crime and freedom improving or collapsing together. Yet this chapter hopes to give a flavour for why Merton and his American successors are equally important to the French building blocks of Durkheim and Montesquieu on the foundations of ancient anomie.

Chapter 3 showed that historians of crime made an important empirical contribution in showing that there is a semblance of something linear about the big picture of crime and violence in human history. Norbert Elias showed how humans faced increasingly complex institutions after the Middle Ages along the journey of modernity. Durkheim was also on that wavelength in the way he saw the importance of emergent complexity in the division of labour created by industrialisation. That institutional 
complexity required emotional self-regulation in the eyes of Elias. This also meant self-regulation of violence and institutional regulation of violence in institutions like schools (even Sunday schools later in this trajectory during the nineteenth century) (Wilson and Herrnstein 1985: 113). Such institutionalisations of the self-regulation of conduct were useful for ambitious parents who wanted to help their children be successful in navigating the emergent institutional complexity that Elias diagnosed.

Yet Elias (1996) himself saw in The Germans that his civilising process of the longue durée would be punctured by decivilising loops. That complexity utterly deflated the intellectual impact of Elias in an academy that prefers simple linear thinking that delivers clear predictions. Social science still struggles to cope with the complex, the nonlinear, a world of more unknowables than knowables and more unknown knowables than knowns. Chapter 3 argued that it is often unknowable how long the lags are in the cascade effects of violence. Some effects might have short lags while other effects simultaneously have longer lags. Some of the bigger violence lags might be intergenerational, as we saw with unusually high rape victimisation of daughters of Australian Vietnam War veterans (O’Toole et al. 2018). This chapter adds to our understanding of why it is the macro picture that matters most to understanding why some times and some places have less crime and more freedom than others. It concludes that analysis paralysis is the wrong response to complex and substantially unknowable macro loops of anomic institutional forces.

If human beings cannot grasp the capability to respond to mixes of linear and recursive explanations that head in contradictory trajectories at different moments of history, sadly, they may ultimately all fall victim to one big crime called ecocide. When ecocide might happen, when the next pandemic will shut whole societies across the planet, can no more be predicted with accuracy before the event than when the Roman Empire would fall. Yet this book concludes that criminologists cannot afford to fiddle only at micro projects when Rome might be burning. So, let us not be excessively pessimistic in spirit as we confront the macrocriminological project, even as we understand that as Elias was writing he was unable to predict that he was soon to lose his family to genocide.

Merton is a good place to start because, by the 1970s, criminologists had become as pessimistic about the capacity of Merton to make policy predictions as they might have been of Elias, had they heard of him. While we cannot predict the next ecocide, the next mass extinction of 
species, the next genocide or the next pandemic, we can know enough about history to grasp that they are likely to arrive again and again. And we can be prepared with useful tools to monitor and steer the outbreaks of disease or violence or extinctions of species as they begin to cascade. We can think in time and game scenarios for countervailing nonlinear dynamics. To steer a better macro future, we can be armed with good questions to ask about the trajectory of crime, inequality, freedom and anomie-the topics of this chapter-even if we are not armed with decisively predictive algorithms.

\section{Robert K. Merton}

Robert K. Merton won no Nobel Prize for work that had profound implications for the social structure of freedom and domination, while his son, Robert C. Merton, was a Nobel Laureate for what might be perceived as technocratic commodification work on derivatives. Merton the son also won the Inaugural Financial Engineer of the Year Award from the International Association of Financial Engineers. It was research on how to game markets. This genre of research was significant in its contribution to domination in the leadup to the Global Financial Crisis. Robert K. Merton's 1938 essay 'Social structure and anomie' in the American Sociological Review was for decades the most cited article in his field (DeFlem 2018). Today, his book that encompasses this work, Social Theory and Social Structure, has five times as many Google Scholar citations as the article (Merton 1968).

Merton's contribution to the study of deviance was motivated in part by his belief that criminology was excessively influenced by the behavioural and biological sciences and insufficiently interested in bigger questions that arise in 'theories of the middle range' about social structure. Merton was very much the sociologist of his day in being more theoretically interested in deviant behaviour than crime, and in fact the place of deviance in a theory of American social structure. In my correspondence with him 40 years ago, he was generous and relaxed with the work of a young scholar who was little interested in theories of deviance in America, who preferred to use his work as an aid to the development of cosmopolitan criminological theory. He would be not only relaxed but also pleased with the internationalisation of his thinking by many other scholars today. 
Merton put a distinctive spin on Durkheim's ideas about the breakdown of the normative order. Merton's anomie was the breakdown of pathways between cultural goals that were a framework of aspirational reference in the normative order and legitimate means for achieving those goals. The rupture between widely shared cultural goals and institutionalised means to achieve them is the crux of Mertonian anomie. For Merton, this is what is fundamental to 'strain toward the breakdown of norms, toward normlessness' (Merton 1968: 217). This quote reveals Merton as closer to ancient anomie and Durkheim than he is often read to be. Like Durkheim, and doubtless like me, Merton is not always consistent in the way he uses anomie. Merton was open to the view that rupture of the normative order might come from other sources beyond the breakdown between cultural norms and the institutionalised means to achieve them. Scholars who chide The Flight from Ambiguity in social science (Levine 1988) might commend the ancients for implanting an ambiguity into anomie that has helped its fertility as an idea!

Merton's theory was applied to his homeland, where a central, widely shared cultural goal was material individual success. Legitimate means to that success was blocked to the poor and to those who performed poorly in school. One result of concern to Merton was a lot of poor people resorting to crime. Merton interpreted the criminological import of his theory to be fundamentally about 'the theory of anomie-and-opportunitystructures' (Merton 1997: 519). The legitimate means for achieving the cultural goal of material success include a good education, a good job and investment. This Mertonian question from late in his career is how to open opportunities when these legitimate means are systematically blocked to the disadvantaged. Merton suggests that American society is characterised by an obsession with the overriding goal of material success, without an equal emphasis on the proper way to achieve it. 'The morality of such a society is summed up by the expression, "it's winning that matters, not how you play the game"' (Box 1971: 104). This establishes the relevance of Merton beyond the crimes of the needy to crimes of the greedy. Andrea Schoepfer and Nicole Piquero's (2006) empirical study of the association between embezzlement and institutional anomie illustrates this relevance. By crimes of the greedy, I mean crime committed by those who have rich access to legitimate opportunities, but who have an insatiable desire to be not just a winner, but also an endlessly bigger winner, even to be number one. Corruption of all institutions arises when those with the vaunting pride to want to be extreme winners care not how they win or 
how they play the game. This is not a modern observation that begins with Sutherland (1983) or Willem Bonger (1916), insightful though they were. Aristotle said: 'The greatest crimes are caused by excess and not by necessity' (1932: Book II, p. 65). It took powerful military institutions to go to the excess of murderously exposing their own soldiers to fallout from nuclear explosions in the 1940s and 1950s.

While history has not researched this systematically, it is perhaps plausible that Merton is right that the goal of material success has been held out as important across most sections of American society for most periods of its history. Conversely, in some societies in Europe and Asia that experienced lower levels of crime than the United States, we can perceive many historical periods when peasants might be deeply disadvantaged but did not perceive it as their lot to aspire to the material success of the nobility or the bourgeoisie. Then, we frequently observe other periods in those societies when the aspirations of underclasses are stirred and rebellion cascades into violence (Braithwaite and D'Costa 2018). This is what Merton was driving at when he said: '[C]rude (and not necessarily reliable) crime statistics suggest that poverty is less highly correlated with crime in Southeastern Europe than in the United States' (1968: 201). As an arrogant young criminologist in my 20s, I argued in correspondence with Merton about this, as well as in a conversation with Merton's mentor Talcott Parsons. They liked to quote Pitirim Sorokin (1928: 560-61) on his (correct) observation that many poorer countries had less crime than rich countries like the United States. Sorokin, Parsons and Merton did not think very clearly about the distinctions between the poverty of a country, the poverty of persons and inequality within rich and poor countries. The evidence warrants some cynicism about how exceptional is Americans' obsession with their 'dream'. I excoriated systematic reviews of the class-crime relationship of that time conducted in the North Atlantic for the way they excluded data and insights from the East and the South. I included a lot of Antipodean data in my literature reviews, as well as data from Nigeria, Uganda, South Africa, Argentina, Japan, India, Sri Lanka, Mexico, Puerto Rico and various more 'obscure' European locales such as Sardinia and Yugoslavia. After traversing this literature, I would chide the American sociologists:

Where are these societies which, lacking differential class symbols of success, show no class differences in criminal involvement? It is reasonable to reject Merton's qualifications and assert that all twentieth century nations for which we have data tend to 
evidence patterns of crime where the poor commit traditional criminal offences at a higher rate than the rich. This seems to be true irrespective of the extent to which differential class symbols of success are present in the society. (Braithwaite 1979-80: 91)

The next page will illustrate with more nuanced recent data from Nepal why my perception of this universal was crude. Young Braithwaite was right, I think, to see Parsons as a genuine conservative who wanted to wilfully misread the systematic evidence on poverty and crime so Americans could take comfort in the belief that sprinkles of equality of opportunity in forms such as scholarships for black students to study at Harvard were the kind of thing needed, while improved equality of outcomes was irrelevant to accomplishing a less criminal society.

While I felt it was Merton who was on the right track, he pandered and conceded too much to the views of Parsons and Sorokin on the limited relevance of structural inequality to crime. Today, I think that in seeing them as myopic specimens of American sociology, I also was myopic. Moreover, our eyes must be open to the importance of Parsons in the way he laid a foundation for institutional anomie theory. Parsons did this by conceiving of what institutions are in an elegant way (Parsons 1990), thereby laying foundations for the 'new institutionalism' across social sciences of which it could later be said that 'we are all new institutionalists now'.

Merton was insightful with his understanding that the common impact of poverty in explaining crime was conditioned by the degree of legitimation in the society of poverty's inevitability, and the degree of acceptance by the poor that their poverty was the natural order of things-something they could not aspire to escape. This chapter diagnoses why there are many reasons for the consistent inconsistency in relationships between poverty and inequality and crime, but it was Merton who in this way put his finger on such an important source of indeterminacy in the inequalitycrime relationship.

Hence, in a society like Nepal (Braithwaite and D'Costa 2018: Ch. 9), the caste system can be settled and well accepted by most sections of society for long periods of history. Then, grievances at particular locales are exploited politically to mobilise lower-caste resentment by Dalits (formerly called Untouchables) and other oppressed castes, and to stir feminist resentment among oppressed women as well. Where inequality for centuries was not particularly associated with violence, a Maoist uprising in Nepal became 
the last successful communist uprising of world history, with the fall of Nepal's monarchy in 2006. In that surge of killing of rulers, inequality between the landlord caste and the peasants at the local level suddenly became highly predictive of which districts had the highest rates of killings by Maoists (Nepal et al. 2011). At a more qualitative level, locales where there was widespread rape of Maoist women by state security forces were where women surged to fight for the Maoist army (Braithwaite 2015). Nepal today has returned to being a high-inequality but low-violence society. While Nepal has not become a Maoist society, Maoists have been able to win, then lose and then win again elections since 2006. Democracy is more consolidated and feminist reforms have been quite impressive from the most politically and militarily feminised insurgency the world has seen (Braithwaite 2015; Braithwaite and D'Costa 2018: Ch. 9). Today, the President of Nepal is a woman who was formerly a Maoist general. Among other feminist reforms, today, Nepal's constitution requires a minimum of one-third of judges to be women, one-third of Members of Parliament and senior civil servants and even one-third of the military and the police. The Maoist uprising was associated with a particularly remarkable improvement in gender equity in health, even as many other inequalities remain or returned to being deep, and implementation of transformation has been fraught (Braithwaite 2015). A peace agreement and law reform to abolish the caste system and legislate for gender and ethnic equality, however, have not hugely diminished the underlying structural and cultural realities of caste, gender and ethnicity in Nepal.

Caste is structurally central for understanding not only violence from ancient times in 'Greater India', but also for understanding freedom. Acemoglu and Robinson (2019: Ch. 8) conclude that even though ancient panchayat traditions energised the popular participation and accountability that Gandhi sought to harness as 'village republicanism', its caste system was a 'cage of norms' and a cage of oppression that stultified freedom as nondomination. For Acemoglu and Robinson (2019), the Greater India that was much wealthier and more powerful than Western Europe during ancient, medieval and early modern times fell behind western economic development during late modernity because it was unable to transcend this deeply structured inequality and normative domination through the caste system, while the West managed to almost completely unburden itself of feudalism. 
There are many of these high-inequality and low-violence societies at the time of writing, such as Rwanda (which, like Nepal, in 1995 shifted to high inequality and high violence). Rwanda's conflict was a cataclysmic upsurge of genocidal violence by the majority ethnic group (the Hutu), which had been economically and politically marginalised from colonial times, against the privileged Tutsi minority. Other societies with very high inequality and low homicide rates include Ghana, Malaysia, Brunei, Hong Kong, Iran, Saudi Arabia, Qatar and the United Arab Emirates. Again, systematic research needs to be done, but studying these societies in a Mertonian frame might have appeal. By this I mean that the poor and women in these societies may suffer levels of inequality and discrimination possibly considerably worse than in the United States, but the aspirations of the poor are more contained than in the United States. This might explain why the United States has experienced many periods of far higher crime rates than these societies. When Merton (1938) first published 'Social structure and anomie', he was more preoccupied with serious adult criminals like Al Capone during a period of escalated US violence (Prohibition). He was more concerned with this than with the juvenile delinquents whose self-reported petty offences became the research mainstay of his scholarly successors of the anomie tradition in the 1960s and 1970s. Likewise, Merton perhaps has his most powerful relevance to the kind of adult genocidal criminality seen in Rwanda, or indeed to how a comparatively low-violence but unequal society like Syria could explode into street violence, terrorism, state violence, ethnic cleansing and war after the Arab Spring of 2011.

As important as Merton is, my mission here is not exegesis on the further dimensions of Merton's contributions, as others have already done that admirably (for example, Passas and Agnew 1997; Messner and Rosenfeld 2013; DeFlem 2018). It is more important to move on to building the idea of opportunities for freedom and opportunities for others to dominate the freedom of fellow citizens, through the work of fine scholars in the American anomie theory tradition, starting with Cloward and Ohlin. 


\section{Cloward and Ohlin and illegitimate opportunities}

Cloward and Ohlin (1960) maintain that if delinquency is to result from the desire to achieve a cultural goal, two things are necessary. First, like Merton, they say legitimate means for achieving the goal must be blocked; but second, illegitimate means for achieving the goal must be open. Within any given community there may or may not be a system of illegitimate opportunities (for example, a criminal subculture that values a subcultural goal of success in drug dealing). Subcultures are important in constituting illegitimate opportunities. They expose neophytes to criminal role models who enjoy success in achieving a generally valued goal like material success by an illegitimate means such as selling drugs. Criminal gangs can also help to constitute such criminal opportunities by supplying protection and on-the-job training in how to make money through illegitimate means. Gangs and subcultures are among the vehicles for Cloward and Ohlin to link Merton's anomie to Sutherland's (1947) and Cressey's differential association theory. A meta-analysis of 179 studies shows that gang membership is a quite strong predictor of criminality (Pyrooz et al. 2016). An important way to explain the extraordinary levels of crime in societies like Democratic Republic of Congo or in Central America are the hybrid forms of criminal organisations in those societies that are more than just drug gangs; they are also organisations that dominate large spaces militarily, fragmenting state monopolies of pacification, trafficking enslaved individuals and putting them to work in criminalised markets to create different versions of corrupted capitalism where markets in vice dominate markets in virtue.

The criminological evidence that illegitimate opportunities are important to explaining crime is large and convincing. At the level of micro opportunities, the literature on situational crime prevention has shown that strategies for regulating opportunities for crime before the event tend to be more effective interventions than strategies for punishing crime after the event. A special issue of The ANNALS of the American Academy of Political and Social Science edited by Joshua Freilich and Graham Newman (2018) is persuasive on this. At the more macrolevel of insight, the work of Shover and Hochstetler (2005) and others shows the importance of lure to understanding patterns of white-collar crime. 
Ecological theories of crime are helpful for understanding the dynamic quality of opportunities. Bank robbery no longer has the importance as a crime problem that it had in the era of Bonnie and Clyde. One reason is that modern security has hardened banks as targets. A more fundamental answer is that the opportunity structure has moved on. It was but is no longer an insight for Willie Sutton to say he robs banks 'because that's where the money is'. Such money as is there may come with dye packs that stain both the money and the robber. Banks are no longer where the money is in the sense of it being found behind tellers' desks. As soon as cash arrives in the bank, it moves to cyberspace, where it can be sliced and diced into securities that are globally mobile. Early this century, the best criminal opportunities then came to reside in fraudulent ways of doing that slicing, dicing and onselling of securities. Cybercrime is where contemporary criminals who lack the capital to trade securities found the money to be-a new frontier of criminal opportunity that supplanted old ones such as bank branches and bundles of cash. Farrall and Karstedt's (2019) data from early this century in the era of the transition to cybermarkets showed that middle-class people who had access to the internet were more than twice as likely to be in the victim-offender group who experienced both high levels of criminal victimisation and high levels of participation in middle-class crime. The growth of the internet this century has driven new market structures of lure and predation across issues as diverse as paedophilia, financial scams and electoral disruption to constitute the modern anomic election. The internet is fundamental to Shover and Hochstetler's (2005) analysis of the 'cornucopia' of new opportunities available to sophisticated criminals. Criminology that continues to evaluate crime-prevention strategies and theories for explaining crime overwhelmingly in terms of theft and violent crime becomes more out of touch with each passing decade. As contended in Chapter 3, analyses of such old-criminology sources of data to show that there was a crime drop since 1992 fail to account for the fact that this was when there was the great rise of new crimes in cyberspace, as testified by the rise in fraud and embezzlement convictions in the United States during this period (Farrall and Karstedt 2019).

Chapter 5 uses the scamming industry in Jamaica to show that even in a poor, high-crime society today, more people make a criminal living from electronic scamming than from theft or robbery and this scamming generates much higher levels of violence than nineteenth and twentiethcentury outlaws with guns blazing breaking into wealthy western banks 
crammed with cash. That Jamaican scamming industry is both about the lure of Cloward and Ohlin's illegitimate opportunities and about blocked Mertonian legitimate opportunities for many impoverished foot soldiers for whom scamming is one of the few jobs they can get (Marsavelski and Braithwaite 2018).

Cloward and Ohlin's contribution is important because, in extremis, the lure of the criminal opportunity can be so large that it is a more important explanatory factor than the blockage of legitimate opportunities. As discussed in the previous chapter, most Australians are occasionally lured to cheat a little on their tax return when presented with an illegitimate opportunity they can get away with. This is so even when they have a good job, a fine education and live in a wealthy country that provides legitimate opportunities for most of them.

This book (like the discussion of earlier evidence in Braithwaite 1979) concludes that the explanatory power of both blocked legitimate opportunities and open illegitimate opportunities enjoys moderately strong empirical support in criminology. A large number of excellent studies using various levels of awareness of limited opportunity measures soon followed Cloward and Ohlin in finding that delinquents perceived their opportunities as more limited than nondelinquents (starting with Elliott 1962; Landis 1962; Short 1964). Short and Strodtbeck's (1965: 268-69) pathbreaking research of this era found that members of delinquent gangs both perceived their legitimate opportunities to be lower than did a sample of non-gang members and perceived their illegitimate opportunities to be greater compared with the non-gang boys.

While Messner and Rosenfeld (2013) back away from the redistributive progressivism of the prescriptions Cloward and Ohlin drew from their work, they make an incisive Cloward and Ohlin point about the great crime drop in the United States from 1992:

As the crack epidemic crested and declined, the illegitimate opportunities for 'making it' through drug selling also diminished. Fortunately, opportunities within the legitimate economy began to grow at the same time, as the United States entered a period of record economic expansion in the 1990s. (Messner and Rosenfeld 2013: 97) 
But what of the problem with this American story that almost all western societies had a great crime rise until 1992 and a great crime drop afterwards? And there is the further qualification that, for the poor, the boom of the 1990s was only in low-pay 'go-nowhere' jobs (which required regulated increases in the minimum wage). Mandated buttressing of such jobs with vocational training was often needed if they were to instead become 'step up the ladder jobs'. Average incomes for working-class families fell between 1960 and 1992 to the point where only with two jobs in the family could people afford to buy a house. As argued in Chapter 3, the key analytical move is to focus not on the crime drop from 1992, but on the great crime rise from 1960 to 1992 because that is the period of exception from the longer-run western historical trajectory, which has been downward or 'civilising', as Elias and Pinker put it.

European societies did not have the crack cocaine epidemic fuelling the extremes of gang gun violence suffered in US cities, which likely was important to the severity of the great American crime rise. On the other hand, the United States mobilised its hegemony to globalise its War on Drugs during this period, which Chapter 3 argues helps explain why, across the northern two-thirds of Latin America and the Caribbean, there was no general drop in crime between 1992 and 2020, but rather, a rise in crime. European police forces might have taken to the war on drugs with less tyranny and more moderation than US police, and more infrequent shootouts with street gangs selling crack. Yet they suffered some of the criminogenic consequences of the War on Drugs up to 1992, after which that war became even more moderated in Europe. But the more fundamental similarity among the United States, Europe, Canada, Australia and New Zealand between 1960 and 1992 is that this period encompasses nearly all of the economic catastrophes of deindustrialisation, which for most of these societies peaked in the 1970s and were mostly slowing by the mid-1980s, though there was one final shock with the 1990 western recession that was driven by overly restrictive monetary policies and an oil price shock. That general deindustrialisation of 1960-92 did not occur in Asia, particularly East Asia, where there was rather a modest consolidation of industrialisation and of impressive job creation of diverse kinds in new tourist industries, the information economy and the service sector; and there was a general drop in violence and crime in Asia during the western crime rise of 1960-92, as Chapter 3 also concluded. 
Rapid deindustrialisation was anomie coming full circle. Durkheim popularised anomie to make sense of the dislocation of the transition to industrialisation and the 'idolisation of wealth' in nineteenth-century France. Japan was the major early exception to this; it continued to industrialise in the 1960s, 1970s and 1980s, producing a higher percentage of the world's automobiles and steel than it had in the 1940s and 1950s. Japan was also the big exception among the wealthiest countries in experiencing a steep, continuous decline in crime rates before 1960, between 1960 and 1992 and beyond 1992. The great crime drop in Japan until 1992 was a drop to exceptionally low crime rates-a longer and bigger trend than in the West in a society with excellent crime statistics. It was so parochial and unscientific for most (but not all) western criminologists to take so little interest in the crime drop in the world's second largest economy while they were so absorbed with the US drop. Hence, like Messner and Rosenfeld for the United States in the above quote, we can make good sense of the macro patterns of crime across all developed economies since World War II with the rise and fall of industrialisation (and the opportunities it provided for working-class people) and the rise of the information and services economy of the 1990s that created new opportunities.

These patterns do not apply to Latin America, Africa and the rest of Asia, which were not yet industrialised societies in the 1960s. Their poor did not suffer the shocks of deindustrialisation at the level that changed working-class landscapes in the West during this period.

Combining old insights from Cloward and Ohlin with new ones from Farrall and Karstedt (2019), we might say that when the working class shrinks and gets poorer, we see greater closure of legitimate opportunities for the working class and greater creation of markets in illegitimate opportunities; when the middle class expands, their greater wealth attracts growth in crimes that target them as victims and also a proliferation of opportunities for petty middle-class crime. The middle-class pattern is complex, however, because the middle class has too much to lose, too much of a stake in conformity, to shoot people while committing serious street crime, and too little capital to rob banks while owning them.

One tweak to Cloward and Ohlin that is attractive for the integration project of explanatory and normative theories in this book is to substitute legitimate opportunities with opportunities for freedom, and illegitimate opportunities with opportunities to dominate others. A limitation of 
this, however, is that not all legitimate opportunities are opportunities for freedom, even if the most critical ones might be. Moreover, many will disagree that illegitimate opportunities should not be viewed as crimes if they involve no domination. Normatively, this tweak is a response to the problem that where prostitution has been legalised, sex work is a legitimate opportunity; where it has not, it is an illegitimate opportunity. This will be a normatively unacceptable response to some; elegant to others. Both formulations have their virtues. My main argument is simply that criminologists should not duck normative choice through spurious claims to be 'value free' about what is legitimate and illegitimate.

It is the domain of crimes of the powerful where this choice is most troubling for scholars of criminal justice. To be one of the Soviet citizens who worked in Stalin's gulag under Cloward and Ohlin's normative frame was to have a job that was a legitimate opportunity. To work in China today disciplining Uyghurs in detention is likewise an opportunity for domination; it is not a legitimate opportunity under a nondomination normative frame. Likewise, it was work of domination to be an interrogator at Guantanamo Bay, Abu Ghraib or Camp Bucca, where Islamic State leader Abu Bakr al-Baghdadi was imprisoned during his radicalisation and recruited so many followers among fellow prisoners. Likewise, it was work of domination to be a private intelligence contractor like Lockheed Martin that trained and supplied the interrogators (King and Cooper 2004; Stockman 2004; Chatterjee 2005). It was a dominating 'legitimate opportunity' to be highly paid for work in western 'extraordinary rendition' of political prisoners to be tortured in Gaddafi's Libya. The latter was worse than work that was legal under US law; it was work that reduced rather than increased the quantum of freedom in the world. A republican rule of law must absolutely forbid oppressive imprisonment for 20 years without trial at sites of tyranny like Guantanamo. Great-power dominations married mercilessly at these gulags when the CIA locked up innocent Uyghurs at the behest of Chinese intelligence operatives. A democracy is required to make a legally defensible call as to whether such individuals are prisoners of war, who are therefore accorded the rights of prisoners of war, or criminal defendants, who are thereby accorded the rights of criminal defendants. Many of those thrust into Guantanamo Bay were as innocent of any crime as many in the gulags of the other great powers. Many were thrust there on the tainted testimony of their political enemies in Afghanistan. Many 'Taliban' were handed to the United States 
by bounty hunters paid wads of cash to fabricate allegations; often they handed over their Afghan political opponents (Braithwaite and D'Costa 2018: particularly Ch. 9).

Doubtless many Chinese, Russian and American criminologists do not see these as fundamental questions for the integrity of their science in the way I do. We return to these normative questions for the field throughout this book, particularly in the concluding chapters. The terrorism industry in the United States, Chinese and Australian criminologies and perhaps others may be the best funded and the most fraught parts of our field. A starting point for excising the excesses of dominations from the field might be to be clear that the definitions of legitimate and illegitimate opportunity must be profoundly normative and political; they must not be 'value free'.

\section{Cohen and the micro-macro}

Albert Cohen (1955) followed Merton by prefacing his theory of male delinquency with the assumption that boys from all social classes begin their school careers with a commitment to traditional success goals. But because boys brought up in poverty are ill equipped to compete at school, more of them become failures in the status system of the school. This failure arising from blocked legitimate opportunities initially engenders shame, resentment and bitterness. Loss of a sense of personal worth can be intensified by teachers who withhold privileges and opportunities from unsuccessful boys, by other students who label poor performers 'dumb' and by the realisation that future job prospects are dimmed by school failure.

Having failed in the status system of the school, the student has a status problem and is in the market for a solution. He solves it collectively with other students who have been similarly rejected by the school. The outcasts band together to set up their own status system with values the exact inverse of those of the school: contempt for property and authority instead of respect for property and authority, immediate impulse gratification instead of impulse control, apathy instead of ambition, toughness instead of control of aggression. The delinquent's conduct is right by the standards of his subculture precisely because it is wrong by the standards of the school. By participating in this subculture, the poor academic performer can enhance his self-image by rejecting his rejectors. The boy's status 
problem is solved by the collective creation of a new status system in which he is guaranteed some success. This can be taken further when the oppositional subculture of a school that can deliver only symbolic rewards is coopted for recruitment by an adult street gang or drug distribution organisation that can deliver the material rewards of a criminal career. The dynamics of rejecting your rejectors by joining a violent subcultural group continues to resonate today as an explanation for the recruitment of stigmatised young people to terrorist cells.

The first proposition of Cohen's theory - that disadvantaged boys are more likely to fail at school than middle-class boys — was strongly confirmed by a wealth of evidence such as Deutsch's (1967) The Disadvantaged Child. It is also beyond doubt that those who fail at school are more likely to engage in delinquent behaviour (Braithwaite 1989). Moreover, Toby and Toby (1957) soon established that poor academic performance precedes delinquency, more than vice versa. This was important because it was plausible that the reverse direction of causality to that posited by Cohen applied: poor performance might result from participation in a delinquent subculture. Although the most fundamental propositions survived the confrontation with empirical evidence, Cohen's theory was vulnerable at a number of points. For example, Downes (1966: 236-39) concluded from his study of young offenders in Stepney and Poplar in the United Kingdom that the typical response to failure was not Cohen's 'reaction formation' but 'dissociation'. Rather than rebelliously turning the values of the school upside down, it was more typical for the British delinquent to simply withdraw interest from the work world of the school. Box (1971: 107-8) also suggested that there was no 'reaction formation' because boys born into poverty, at least in the British context Box studied, did not 'internalise' the status criteria of the school in the first place; they simply could not 'be indifferent to' the status criteria of the school. For Matza (1964), the intervening variable between failure in a status system and delinquency was 'drift'. This was such an elegant synthesis of these dilemmas:

The delinquent belongs to a subculture characterized by values which allow delinquency but do not demand it. The delinquent is neither compelled nor committed to deeds nor freely choosing them; neither different in any simple or fundamental sense from the law abiding, nor the same ... He is committed to neither delinquent nor conventional enterprise ... The delinquent transiently exists in a limbo between convention and crime, 
responding in turn to demands of each, flirting now with one, now the other, but postponing commitment, evading decision. Thus he drifts between criminal and conventional action. (Matza 1964: 28)

Drift may still be equally elegant in its application to Farrall and Karstedt's (2019) middle-class criminals. Drift, nevertheless, had special appeal for the disengaged drug offender in comparison with materially ambitious property offenders. Irrespective of whether disadvantaged children 'internalise' or 'can't be indifferent to' the status criteria of the school; irrespective of whether the response to failure is shame or rebellion; irrespective of whether there is 'drift', 'reaction formation' or 'dissociation'; regardless of whether differential association with delinquent peers following rejection by the school is critical or not-the fact that school failure and domination at school ultimately encourage delinquency is the big Mertonian point. That remains the big picture of blocked legitimate opportunity and anomie. Being unfree has the sense of domination across many of these formulations: 'Being pushed around puts the delinquent in a mood of fatalism. He experiences himself as effect. In that condition he is rendered irresponsible' (Matza 1964: 89). Domination is particularly critical when people are 'pushed around' in ways they perceive as unjust or oppressive, because a sense of injustice can abrogate the moral bind of law. 'The subculture of delinquency is, among other things, a memory file that collects injustices' (Matza 1964: 102). Again, Farrall and Karstedt (2019) say the same thing about petty middle-class offences on their padded insurance claims and their tax returns. The same might be said of business subcultures of resistance to regulatory or tax laws that share narratives about the excessive taxation of free enterprise and regulation that cripples the economy with red tape (Passas 1990). Business subcultures that encourage corporate crime are now well documented in the criminological literature (Simpson 2002). Mexican and Colombian drug 'cartels', street gangs in US cities, Japanese yakuza, Chinese triads, Russian organised crime-all clearly exist. On both sides of the long war in Afghanistan, murderous Taliban and Islamic State units and murderous special forces units of western militaries - such as those currently facing war crime prosecutions in Australia in respect of 55 alleged crimes against humanity-existed as criminal subcultures. Operatives on both sides believed they were doing God's work to eliminate evil as they committed uncounted war crimes. 
Much of the stuff of illegitimate opportunities in an increasingly complex society is in the nature of knowledge about how to do it; this knowledge is largely preserved and transmitted by subcultures. Granted, most of the groups that transmit these subcultures are not highly organised. Typically, they are loosely structured, even brittle, social organisations. Most crime is not perpetrated in organised gangs; the majority of juvenile offences are deeds done in groups of two or three (Zimring 1981). Victim surveys suggest that much adult crime is a more solitary affair. This is less true of state crime, which tends to be highly organised under formations like secret police units that educate inductees in how to disappear targets and how to waterboard or extract fingernails from them first to get intelligence. In this sense, counterterrorism units can be schools for terror. Even solitary crime of all types is often made possible by a learning process that occurs within loosely coordinated groups that provide support for solitary crime in the form of social approval, neutralisation or transmission of knowledge of how to do it.

It is of course unnecessary for schools to dominate. They do not need to be the mouse race that prepares children for the adult rat race. Redemptive schooling can allow all children to succeed against their own past performance. Those who are not good at sport can be helped to find a form of physical activity at which they improve and which they enjoy. All children can be found to be outstanding at something and can be helped to improve against their own past performance in education outcomes. Groß et al. (2018) showed with multilevel data from 4,150 students in 69 German schools that schools with a 'competitive/egoistic school culture' experienced higher levels of youth offending.

If we value education, if we are open to learning lessons from Albert Cohen, students can be free to opt out of schooling. They can be provided liberated alternative pathways in educational institutions that give them the right to choose to learn the kind of things they value learning. Even if these are not the best choices about what to learn, in that they exclude mathematics, for example, it is best for students together with their parents to be free to make the choices that will at least allow them to receive guidance in the art of learning how to learn. In such a world of freer education, most children will continue to opt for conventional schools, though perhaps only if these schools learn to be sufficiently redemptive to hold the students who are most at risk of educational anomie. This is what their parents will want to do and this is what most will choose. Those who do opt out will often be students who have disruptive impacts that 
we now know substantially reduce the learning of all the other students in conventional schools. The founders of the International Institute of Restorative Practices, Susan and Ted Wachtel, have devoted lives well spent to arguing for the right of children to opt out of school and into self-directed education (www.buildinganewreality.com/learning-isnatural-school-is-optional/). They have built schools that accept children who have been thrown out of so many schools for crime and behavioural problems that no school will now accept them. Paul McCold's (2008) study of 1,636 children with behavioural problems sent to the Wachtels' restorative schools found a 58 per cent reduction of reoffending for those who completed the program. This impact reduced after two years, though the percentage reduction in offending was greatest for children with the highest risk factors for offending.

Anomie theory in its Mertonian form is not a theory of why some individuals offend and others do not. It is a macro theory about how institutions like schools are run, about how poverty and inequality are constituted by economic institutions to block legitimate opportunities and open illegitimate opportunities. In this book, the kind of blocked legitimate opportunities that matter most are opportunities to be free, to be liberated from domination by others and by institutions. And the kind of illegitimate opportunities of concern are opportunities to dominate others. This, of course, is a narrowing of Merton to an even more circumscribed middle-range theory. A large tradition of American criminology dubbed 'strain theory' has translated Merton to the microlevel of predicting which kinds of individuals will offend. This tradition of anomie theory fosters microlevel testing of anomie theory that supports its credibility (Agnew 2016), often without testing it at the macrolevel of the institutions at which Merton pitched his theory. That is not to say that work in this tradition has limited value. A good example of movement from the micro to the macro is Kaufman et al.'s (2008) analysis that African Americans experience more strain through justice system discrimination and criminal victimisation and more economic, educational, familial and community strains and that this explains higher rates of African-American offending (Unnever and Gabbidon 2011: 17-18). 


\section{Pluralising by Messner and Rosenfeld}

Mertonian seeds were falling on stony ground in late twentieth-century criminology because his work was read in those decades as a theory meant to explain why some kinds of individuals commit crime and others do not, when in fact it was a theory of how some institutional configurations are conducive to rule-breaking. An influential example of this kind of empirical critique of anomie theory was Ruth Kornhauser (1978) questioning the association between delinquency and the gap between American individuals life aspirations and their opportunities. Up to the present, studies have found associations of this kind, but inconsistent ones, and sometimes weak ones, between self-reported delinquency and measures of rupture between the aspirations of individuals and blocked opportunities (Agnew 2016).

At the same time, the data continue to show that very poor young people are more likely to break the law, especially with very serious offences (Agnew 2016). For example, African Americans (an overwhelmingly poor minority) accounted for 52.5 per cent of all homicide offenders in the United States between 1980 and 2008 (Cooper 2012). The truly disadvantaged in all societies are especially likely to go so deep into the justice system as to fill prisons. The evidence continues to show that individual poverty in combination with poverty in the area in which one lives remain strongly associated with crime (Braithwaite 1979; Agnew 2016). Indeed, the relationship between the two is multiplicative rather than additive (Braithwaite 1979). At the macrolevel, poverty, racial disadvantage and inequality continue to bear strong relationships to crime, as do what came to be known as institutional anomie theory variables (Pratt and Cullen 2005). Patterns do vary, but I will argue that recurrent inequality and poverty associations are similar in pattern and just as strong for international comparisons of crime rates and comparisons among societies, cities and neighbourhoods today as when Braithwaite (1979) traversed this literature.

Perhaps it takes an old-fashioned, white, male criminologist today to admire the work of Merton, Cloward, Ohlin and Cohen, not to mention Durkheim. I relished conversations with three of them and about them with Ian Taylor, which included laughs about a British Journal of Criminology review in which Ian found my Inequality, Crime and Public Policy a 'curiously anachronistic text' with the 'character of a treatise 
from the 1950s' particularly because of my 'faith in the effects of social democratic state intervention in the class structure' and 'disingenuous faith' in the 'development of public housing policies' (Taylor 1980: 184-85). Not only was this research that those on the right would hate, according to Ian, it was of 'no interest to the Left'. This was all pretty correct. ${ }^{1}$

In a way, Merton, Cloward, Ohlin, Cohen and Cressey suffered the same fate in the United States in a more visible way because the War on Poverty, Mobilization for Youth and the President's Commission on Law Enforcement and Administration of Justice in the 1960s were significantly influenced by their ideas. Richard Cloward personally worked on Mobilization for Youth in Manhattan. Such War on Poverty programs generally did not succeed in transforming America. As Ronald Reagan's putdown of attempts at social democracy beamed, the 'government declared war on poverty and poverty won'. The programs spectacularly failed to prevent three more decades of rising crime and six decades of rising inequality.

Feeling the criminological fossil as I did then and now because of this circle I admired, I was grateful for the impact of the work of the institutional anomie revivalists Steven Messner and Richard Rosenfeld (2013). Their work in this tradition since its initial publication in 1994 has had not

1 Still, I take a strange comfort in the fact that another emeritus, Robert Reiner (2020), could have been publishing such a soulmate of a book to this one, with the title Social Democratic Criminology, at the same time as I finished the fourth draft of this one, and that the book of such a fellow fossil could even be published in a series called New Directions in Critical Criminology! I loved Reiner's book. When it was insisted that I say something about the concrete contributions I had made to social democratic politics on the occasion of being made a life member of the Australian Labor Party, I genuinely was at a loss to think of anything credible. I mention this partly because social democratic politics continues to play an important role in the normative and explanatory frameworks of my criminology and life. When I won a scholarship from my dad's trade union to support my education, in presenting the certificate, the head of the union graciously opined that he was not sure these scholarships were a good idea because they helped kids to grow up to become Tory voters. I promised him I would not become a Tory voter! Readers should know what kind of politically active person I am so they can make their own judgements about how this colours my work. I have doubts whether Ian Taylor was even right that my work might have found favour among social democrats of the 1950s. I remain content to choose to make the case that criminology is politically dangerous if it lacks normative moorings to prevent threats to freedom. Then there is satisfaction in laying out a theoretical viewpoint on what kind of criminology, moored to what kinds of norms and what kinds of politics, might be associated with better or worse outcomes for crime and freedom. That is a project of contesting with criminological colleagues what sort of theory of crime and freedom is useful to humankind and other species. This can be agonistic (Chapter 12) and need not appeal to any political leader of any state. It still might resonate with enough people to have some prospect of being viewed as worthy at some future time. The test is whether it adds something to an improved conversation about crime and freedom. 
only much more impact than my own on inequality and anomie; it has also fuelled a suite of encouraging research findings, especially in the past decade. Their contributions renewed hope that perhaps fossils can return to life to add a little to the enthusiasm for Merton, Cloward and Ohlin and Cohen that Messner and Rosenfeld renewed.

Messner and Rosenfeld viewed the most conspicuous limitation of Merton on anomie as being its exclusive focus on a single facet of social structure: unequal access to legitimate means to success. This has now been shown empirically to be the key theoretical move contributed by Messner and Rosenfeld. Messner and Rosenfeld insightfully diagnosed problems of American society that go beyond its economic institutions. Indeed, it is a diagnosis about economic institutions being overly dominant over all other institutions. For Messner and Rosenfeld, crime levels can be explained by the degree of countervailing power of non-economic institutions - specifically those of the family, the education system, the welfare state and the polity-against economic institutions.

Like Merton, unfortunately, Messner and Rosenfeld initially framed their story parochially as being one about the American Dream. Here the data are not encouraging that there is anything exceptionally American about the 'American Dream' (Chamlin and Cochran 2007). Let us consider that limitation first before revealing the virtues of a more cosmopolitan reading of the power of the theoretical insights of institutional anomie theory. The next section argues that the American Dream as something distinctively American is, like America as the 'land of the free', part of an American myth-scape that is wanting in comparativist empirical foundation.

\section{Keeping American exceptionalism in perspective}

Criminology has been obsessed with American exceptionalism to the neglect of more strategic and multiplex comparisons. Perhaps this is because so many leading criminologists are American. Nevertheless, criminologists across the globe embraced the specificities of institutional anomie theory for application to their own societies for the good reason that helpful insights were on offer. Merton's anomie theory and Messner and Rosenfeld's (2013) that built on it are theories of something distinctively American. If we look at homicide data—which is imperfect 
but the most meaningful crime category for international comparisonsit is true that the United States has a higher crime rate than European societies or other developed economies (adding other non-European comparator developed economies like Canada, Australia, New Zealand, Japan and South Korea). But in the wider sweep of comparisons across all societies, while the United States might have had a comparatively high crime rate during and after the peak of the crack cocaine epidemic in the 1980 s, and perhaps during the internationally unusual increase in gang killings at the height of the prohibition of alcohol during the 1920s when Merton was finishing his education, the extent to which the United States was ever an outlier of extreme violence has always been modest since the wars of its western frontiers receded. Today, after the great crime drop since 1992 (discussed in Chapter 3), the US homicide rate, at 5.3 per 100,000 , is actually below the global officially recorded homicide rate of 6.2 .

US exceptionalism is more about the punitiveness of its culture of control (Garland 2001), for which its only competitors in imprisonment rates have been Russia and South Africa. The United States has been exceptional among developed economies in retaining capital punishment, though use of this has historically moderated substantially in the United States, as it has in the other countries that are most genuinely exceptional in the heavy use of capital punishment, China and Iran. The United States is like many societies that have a large number of neighbourhoods with exceptionally high crime rates that are responded to very punitively, and a much larger number of neighbourhoods with exceptionally low crime rates.

So, the balanced way to view the United States is as, on average, only a high crime rate society compared with other developed economies, and only high at its hotspots. Chapter 3 concluded that the exceptionally highhomicide societies are overwhelmingly to be found in Latin America, the Caribbean and Africa. My temptation is to see whether what is distinctive about these highest-homicide societies is the same as what is distinctive about the United States compared with the lower homicide rates of other developed economies. It is that these high-homicide societies, whether in Latin America, the Caribbean or Africa, are societies still recovering from the Atlantic slave trade, still recovering from other forms of intergenerational trauma associated with other kinds of great waves of violence (drug wars, civil wars, Apartheid), and societies still with high inequality and with a major armed gang problem among the excluded. On the African side of the Atlantic, so many societies have never fully 
recovered from colonialism and from the internal conflicts associated with capturing outgroups and selling them to the Americas as slaves on a massive scale. It has long been established that export of the largest numbers of slaves from Africa to the Americas is a predictor of the worst national economic outcomes. New data for 2SLS instrumental regressions from Schargrodsky and Freira (2021: 48) shows that cross-nationally 'African slaves received' and being an ex-colony are also predictors of homicide rates. South Africa is a distinctive case of a society with some of the highest-homicide cities on the planet outside the Americas. It is a society in which the sins of enslaving indigenous black peoples were compounded by Apartheid as a distinctive post-slavery form of violent racial domination that bore a functional equivalence to slavery. Most societies on the opposite side of the Atlantic are still recovering from the domination, the deprivation of freedom, the flogging and the torture that were slavery. In many parts of Latin America, indigenous peoples were also flogged into slavery and submission to work in plantation economies. These were the survivors of a transcontinental genocide from which First Nations Americans have never recovered.

As an outsider looking at the United States, it seems that the greatness of Abraham Lincoln in US history is not that he was a war leader who selected great generals to defeat the southern enemy who actually should have been easier to tame than these northern generals found. No, the greatness of Lincoln was as the leader who was able in his best speeches, such as the Gettysburg Address, to re-story what it is to be an American (Meister 1999). To be an American-North or South, black or white, slave or free-is to be a person who is recovering intergenerationally from a deeply structured institution called slavery. Likewise for South Africa, Nelson Mandela was the historic leader who could re-narrate what it was to be a South African. Black or white, European, Boer, African or coloured, to be a South African is to be a citizen in recovery from an institution of unfreedom called Apartheid. Sun Yat-sen could re-narrate being Chinese as being a survivor of colonial domination, dynastic domination and warlord domination.

In a similar way for my own country, to be an Australian-Aboriginal, Torres Strait Islander, white or Asian-is to be a victim of the genocide of the frontier wars, of the nineteenth-century anti-Chinese pogroms, of the vilification of Asian boatpeople and their stigmatisation by anti-Asian political parties of the far right. The overrepresentation of Indigenous Australians in Australian prisons is worse than the overrepresentation of 
African Americans in US prisons. The difference is just that this does not drive up imprisonment rates or affect homicide rates in Australia to the degree that racial domination does in the United States because Indigenous Australians are a much lower percentage of the population. In fact, First Nations Americans are also greatly overrepresented in homicide arrests in the United States and in imprisonment rates. It is just that Indigenous Americans are not the statistical drivers of homicide and imprisonment statistics that African Americans and Hispanic Americans are. This is because, in Australia and the United States alike, genocide was so totalising in frontier wars and ethnic cleansing combined with European diseases. They wiped out indigenous populations within remarkably short periods. The same history of rapid depopulation of indigenous peoples from the plains and their rapid filling of prisons is true of other major white settler societies such as Canada and New Zealand. This is in contrast to the white enclave colonies where small white populations came and went, such as India and China.

The indigenous genocide was a more massive bloodbath in Latin America than in the English settler continents of North America and Australia. Latin America was much more densely populated by indigenous peoples. Tens of millions of them were slaughtered in genocides by the Spanish and Portuguese invaders. Again, one must ask oneself whether scars of the scale of this indigenous slaughter are still relevant to understanding the extreme violence of both civil war and homicide in societies like Colombia, El Salvador and Guatemala in recent times. The historical cascades of intergenerational trauma and crime-war violence in my theoretical work contend that it could be relevant (Braithwaite 2020a).

Empirically, the American Dream is not so exceptionally American (Chamlin and Cochran 2007). Comparing the world's two most powerful economies, it is common for China specialists to argue, partly based on public opinion data, that aspirations for material success might actually be stronger and wider in China than in the United States. Cao's (2004) data on Mertonian anomie, however, find little difference on the measure between US and Chinese samples, with the United States slightly higher. Cao (2004) systematically failed to find that Mertonian anomie is uniquely strong in the United States. Levels of anomie in the United States are comparable with those in other English-speaking societies and lower than in continental European and Latin American societies. It is noteworthy in this study that the society with by far the highest Mertonian anomie score was the society with the second-highest homicide rate in 
the study, Mexico. The only country with a higher homicide rate than Mexico in the study, Brazil, also had a notably higher anomie score than the United States.

Hence, a weakness of anomie Américaine in the writing of Merton (1995) and Messner and Rosenfeld (2001) is that it is parochially American, failing to examine critically with a cosmopolitan theoretical imagination whether the American Dream is American. This criticism might also apply to the meta-analysis of Pratt and Cullen (2005), which, in showing that the evidence does support the propositions of institutional anomie theory, includes some non-US data, yet seems to bias the meta-analysis in favour of studies published in US journals (Pratt and Cullen 2005: 388, footnote 3). That does not mean that the fundamentals of the conclusions of Merton, Messner, Rosenfeld, Pratt and Cullen are wrong; this book concludes that, in the fundamentals, they are right.

In spite of the failure to demonstrate that the American Dream is a distinctively American driver of unusually high crime in America, the contributions of anomie Américaine remain richly attractive. Mine is just another contribution by an old white male who has not been as distinguished a contributor to anomie theory as these Americans. I will argue, however, that feminist criminology, corporate criminology, postcolonial criminology and international criminology, among others, are deepening the insights of institutional anomie theory. Another ambition is to reboot anomie Américaine by connecting it back more strongly to anomie ancienne. This means connecting the concept back to rapid, destabilising social change, as opposed to anomie being a stable characteristic of American social structure. It also means reframing anomie as a globally cosmopolitan theory in a way Messner and Rosenfeld themselves have now done in an admirable fashion through their crossnational empirical work.

\section{Tempering institutions}

While we should be ambivalent about the American Dream aspect of the Mertonian anomie tradition, what is particularly valuable about the way Messner and Rosenfeld contribute to it is the imperative to temper the influence of economic institutions with influence in the social structure from balancing institutions. In this fundamental way, there is a cosmopolitan influence in the theory that delivers its greatest strength. 
Messner in particular has followed through on this with a huge volume of quality cosmopolitan empirical work. At one point in their book, Messner and Rosenfeld discuss the risks from the economy taking precedence over social institutions and colonising other institutions in conditions of neoliberalism-for example, with the 'fetishism of money' (Taylor et al. 1973: 94). Messner and Rosenfeld even use the word 'tempering' to refer to that balancing by the institutions of education, family and the polity. This is Elliott Currie's (1991: 255) Mertonian point about the pathologies of contagion from a market economy to a 'market society' in which the pursuit of market values is not regulated to be limited to accomplishing certain circumscribed ends. Rather, commodification infects all areas of social life.

Freda Adler's research on low-crime societies was also an influence. Adler (1983: 131) emphasised low crime rates in societies as different as Saudi Arabia, Bulgaria, Japan and Switzerland through strong commitments to familial institutions providing a mooring during times of instability for the wider normative order. For Messner and Rosenfeld (2013), schools are also important for inculcating tempering beliefs, values and commitments that are different from those of the marketplace-less so, this book argues, when schooling is commodified as a mouse race. A stabilising and balancing strength of Confucian societies against market hegemony - such as in Taiwan, South Korea, Japan and Singapore-is that teachers and professors widely enjoy lifetime reverence from their students. In East Asia, it is such a touching experience to go for a drink with a Chinese police chief in his sixties and a junior female academic who taught him in his master's course and to see the older man show the young woman so much deference, respect and honour. The problem with market institutions is that, by design, they have the least self-restraint and are the most laissez faire of all major institutions. This is the danger that lurks behind capitalist commodification that must be tempered by other institutions. Confucian reverence for the teacher above reverence for the dollar is simply an example of this.

While the United States might have the best universities, we must look beyond its shores to find the societies in which schools are the best funded and the most innovative, the teachers are most revered and the outcomes on internationally standardised reading, mathematics and other capabilities are most impressive. This is Messner and Rosenfeld's point about the weakness of the United States at balancing the dangers of its economic institutions with the strengths of its educational institutions. 
The familial and educational institution weaknesses are intertwined in Messner and Rosenfeld's analysis because US parents simply do not spend enough time with their children to nurture and support their learning and social maturation outside school hours. Chapter 7 further develops this theme of how fundamental are mutual interdependence and support between institutions of human capital, social capital, recovery capital and restorative capital formation.

Messner and Rosenfeld point out that the United States is an exceptionally laggard society in terms of paid parental leave and corporate openness to job-sharing by husbands and wives during peak childcare years, flexible family-friendly working hours, employer-provided child care and other pro-family labour market regulation and economic policies. As a result, Messner and Rosenfeld lament that American families sit down to fewer meals together than they did in the decades after World War II. Such pro-family ensembles of policies and labour market institutions are hypothesised by Rosenfeld and Messner to be fundamental to forging a low-crime society. One might add that children in other developed economies do not need to forgo visits to the doctor, other health professionals or the purchase of medicines because their parents cannot afford them, in the way this is sadly common under comparatively weak US welfare-state institutions.

Institutions of gender equality are also relevant here. Because the evidence is that women's prioritisation of an ethic of care in families is more healthily in balance with materialist and careerist values, institutions of gender equality can be helpful in resisting the commodification of everything, just as they can be useful in resisting the unfreedom of patriarchal domination discussed later in this chapter (see Applin and Messner 2015). Halpern (2001) showed that self-interested values are much higher in men and that self-interested values in combination with high inequality and low social capital explain national crime rates as measured by the International Crime Victims Survey.

Institutions that are fundamental to freedom and the low-crime society depend on the effective functioning of other institutions. These other institutions must be enabled to deliver on their distinctive institutional functions. The interdependence among institutions of education, family, the labour market and health and welfare (particularly for children with the gravest developmental deficits) is perhaps the most profound example of this crux of social capital formation. It is the failure of these 
institutional interdependencies that explains why prisons have become the most important mental health institutions for children who grow into young adults with mental health or intellectual challenges. The problem of prisons as the new institutions for the mentally ill exists in all western societies, but in some more than in others.

The lack of support for and supervision of children also have adverse implications for crime control through weakened guardianship in neighbourhoods and denuded capabilities for the cascading of collective efficacy, which are theorised to be fundamental to crime control in Chapter 11.

Chapter 7 argues that public provision is the essence of universalised excellence in education and health. Markets in education and health leave too many gaps to be able to deliver this. Marketised education and health care are prone to gamed outcomes at times when they should professionally commit to the intrinsic importance of education and health outcomes. Markets have a place in delivering innovation to education and health care, yet these are benefits that must be checked and balanced by institutions of public provision and regulation of private markets in public virtue.

Messner and Rosenfeld (2013: 76) are on the same track as this book when they chide Merton for walking away from one particular strength of Durkheim's thinking on anomie. This is that Durkheim was attentive to the issue of how societies regulate appetites to keep them realistic and indeed how normative orders regulate themselves to repair the ship of normative order at sea. This book argues that plural institutions can shape aspirations for humble pride that eschew vaunting pride-narcissistic pride, in Eliza Ahmed et al.'s (2001) theoretical and empirical work. The humbling of appetites becomes imperative when order and civility begin to crumble in societies at times of crisis (from war, the breakup of empire, pandemic, hyperinflation, famine or environmental collapse).

The stasis of Merton in comparison with the dynamism of Durkheim makes Durkheim more relevant to the sociology and politics of regulating crises. An example is the literature on anomie and rapid crime increases in Russia and other countries behind the Iron Curtain after the collapse of the Soviet Union (Kim and Pridemore 2005; Pridemore 2005; Zhao and Cao 2010). 
Messner and Rosenfeld's (2013) institutional anomie theory took Merton's American brand of thinking about anomie out to a much broader conception. In a rather Mertonian way, Messner and Rosenfeld see all societal institutions as being shaped by structural and cultural imbalances between economic and other institutions-notably, the family, the polity, religion and education. Markets, they argue, must be embedded in and intertwined with the institutions that balance them. This, I will argue, is right, while I also argue that we must temper markets to make them stronger if our objective is to reduce domination. Institutional anomie occurs when the economic sphere is dis-embedded and shakes off the balancing, the countervailing power, of other institutions. 'Commodification'-market values that reduce all other values to their worth in economic markets-comes to dominate other institutions in conditions of Messner and Rosenfeld's institutional anomie.

In this sense, institutional anomie takes us close to what political economy writers call neoliberalism-a state of affairs where markets and market values are ascendant on all fronts. The remedy is embedded autonomy for the multiple institutions that build developmental states (Evans 1995). Untempered markets and unbounded commodification are conducive to crime (both violent crime and property crime). This is because unbounded tyrannies of markets sharpen perceptions of injustice and create legal cynicism (Sampson and Bartusch 1998) and cynicism towards the wider normative order. Karstedt and Farrall (2006) call this 'market anomie', in which the profit motive is not balanced by other concerns such as protection of the weak, fair play and the rule of law. Moreover, markets that are cut off from countervailing accountabilities to other institutions are at risk of becoming criminalised. It should be added that the commodification of politics captured by markets also conduces to the criminalisation of the state.

For Messner and Rosenfeld, it is important that the institutions that balance markets sustain their ability to regulate naked pursuit of interests. They see a loss of institutional integrity when balancing institutions are captured hegemonically by the quest for material success. For example, Messner and Rosenfeld (2013: 78) argue that 'education is regarded largely as a means to occupational attainment' in pursuit of economic success. Institutions captured in this way fail to deliver to citizens what we discuss in Chapter 7 as CHIME (Connectedness, Hope, Identity, Meaning and Empowerment). CHIME is a countervailing bulwark against anomie. 
Domination by markets weakens the capability of other institutions to enhance human wellbeing, check the abuse of power and therefore weave the web of controls that prevent crime.

\section{Evidence and institutional anomie theory}

Operationalising the institutional anomie theory idea of the strength of non-economic institutions as a balance to criminogenic market anomie has been attempted in various indirect ways, mainly by testing relationships between crime and structural antecedents in the form of the strength of countervailing institutions. In Pratt and Cullen's (2005: 399) meta-analysis of macrolevel predictors of crime, by a good margin, the strongest of 31 predictors was the 'strength of non-economic predictors' that operationalised institutional anomie theory. This result was based on a small number of studies, though further studies have continued to be encouraging since 2005, without being totally consistent. Messner and Rosenfeld (1997) and Savolainen (2000) deployed a 'decommodification index' that combined several measures of the strength of welfare-state policies. Both studies confirmed institutional anomie theory predictions. Savolainen found from two cross-national comparisons that countries that protected their citizens from the vicissitudes of market forces through strong welfare states were protected from the homicidal effects of economic inequality. Within one US city, Cancino et al. (2007), in a kindred way, supported institutional anomie theory, finding that the criminogenic effect of areas of concentrated disadvantage was ameliorated by welfare generosity. Hughes et al. (2015: 100) found only mixed support for institutional anomie theory in a cross-national study of 50 countries, but they did find that 'homicide occurs most often in countries where free-market principles and practices drive the economy and where core cultural commitments are oriented toward achievement, individualism, fetishism of money, and universalism'. Rudolph and Starke (2020) found cross-nationally that a strong welfare state suppresses crime, mainly through social support and generous unemployment benefits, but did not support a decommodification explanation. In Rudolph and Starke's (2020) review of 41 published studies, only nine reported negative, mixed or disconfirming results, while the other studies showed that a stronger welfare state was associated with less crime in cross-sectional or time-series studies. 
Chamlin and Cochran (1995) tested a combination of the strengths of three non-economic institutions: families (measured by divorce to marriage ratios), religious institutions (measured by the rather Christian index of church membership) and engagement with political institutions (measured by voter turnout). They found that strong non-economic institutions ameliorate the criminogenic effect of high levels of poverty in a comparison among US states. Piquero and Piquero (1998) likewise measured the strength of familial, political and educational institutions and found some evidence for institutional anomie theory. Bjerregaard and Cochran (2008) also revealed that the strength of these institutions was important to explaining homicide and theft cross-nationally, though it was more important in moderating the relationship between inequality and crime than in mediating it. Weld and Roche (2017) tested crossnationally the effect of time-use surveys to compare the time spent working in economic and non-economic institutions and did not find statistically significant effects on homicide rates. The time spent by individuals in different institutions does not seem to be a strong measure of the sway of such institutions.

Chamlin and Cochran (1997) found that property and violent crime were lower in US cities where altruistic commitment to civil society institutions was stronger as measured by charitable donations. They found that, at least among developed economies, homicide and robbery were worse where more people believed work was about making money and more disagreed that 'Less emphasis on money and material possessions is good'.

Since Pratt and Cullen's (2005) meta-analysis, further research has been overwhelmingly encouraging and consistent with its fundamental findings. Nivette's (2011) meta-analysis found that, consistent with various aspects of the institutional anomie discussion above, the predictors of homicide with the strongest mean effects were a Latin America and Caribbean regional dummy variable, income inequality indicators and the 'Decommodification Index'. The Decommodification Index is based on Esping-Anderson's concept of decommodification and has been widely deployed, including by Messner and Rosenfeld themselves, to operationalise institutional anomie theory. It measures protection from the severity of the market by combining measures of social welfare as a percentage of GDP, average annual benefits per capita and sometimes other welfare measures. Nivette's (2011) results are also strongly consistent with Pratt and Cullen's (2005) results from their systematic review at other levels of analysis. 
Some more recent international comparative studies have supported institutional anomie theory for both property crime and violent crime cross-nationally (Cochran and Bjerregaard 2012) or have supported institutional anomie theory for differential violent crime rates between countries but not for property crime (Bjerregaard and Cochran 2008). Using the World Values Survey, Chen et al. (2021) found strong support for an institutional anomie effect measured as countries having high levels of pecuniary materialism among managers in supervisory roles reporting a willingness to engage in ethically suspect behaviours. Tuliao and Chen (2019) also supported institutional anomie theory in this way, using World Values Survey data to discover an economic inequality effect and the effects of the strength of non-economic institutions of family, education, polity and religion. Likewise, Hövermann and Messner (2019) were able to show on a sample of 84,398 individuals from 58 countries both the individual effects of a 'marketised mentality' and the societal effects of institutional imbalance. This study again showed that enfeebled religious institutions enabled justification of instrumental offences. It built on an earlier study of the willingness to excuse behaviours such as bribery, tax cheating and fraud by Cullen et al. (2004), which provided more mixed support for institutional anomie theory. Chamlin and Sanders (2013) explored levels of drug trafficking among 43 European states using aggregated measures from the European Values Survey of the acceptance of material success goals, absolute and relative deprivation, and interaction terms between material success goals, absolute poverty and relative inequality (Gini). All these predicted drug trafficking in accordance with institutional anomie theory.

Other studies after Pratt and Cullen's (2005) review have been supportive of institutional anomie theory at subnational levels of analysis for property and violent crime. Baumer and Gustafson (2007) used US General Social Survey data measures of commitment to monetary success goals to predict place-based rates of robbery, burglary, larceny and auto theft. Crime was higher in areas where commitment to monetary success was strong and commitment to legitimate means was weak. The tendency for this goals/ means rupture to translate into higher rates of crime was reduced by higher levels of welfare support and more frequent family socialisingconsistent with Messner and Rosenfeld (2013). Stults and Baumer (2008) elaborated on these effects, also showing that they arise in areas with 
high property crime, drug market activity and an unbalanced pecuniary value system, and that property crime more often leads to homicide when structural disadvantage is high.

Low educational and economic attainment and high inequality in this now considerable literature tend to enhance institutional anomie effects. This resonates with Albert Cohen's contribution to the tradition from the perspective of schools as institutional generators or suppressors of anomie and delinquency. As some institutional anomie researchers have put it, the results are consistently inconsistent on how or whether the effects of the strength of non-economic institutions moderate or mediate the effects of economic institutions on crime. More is unsettled than settled in this literature, yet I have shown that there are some core effects that are increasingly settled and strong.

Steven Messner has begun through his empirical work to adapt the theory to cover more institutional checks on market hegemony-first, for religion, which was neglected in his original formulation with Rosenberg. While churches no longer temper economic institutions to the degree that African-American churches did in the United States in previous centuries, churches continue to do that in a huge way in many societiesfor example, Pacific Island nations. Likewise, in some Muslim societies, mosques do extremely important work in regulating crime and regulating markets (indeed, they do important work in regulating Muslim crime inside western societies as well) (Wardak 2018), as do monasteries in many Buddhist communities.

Messner co-authored a study that showed that the progressiveness of tax systems was another empirically relevant institutional tempering of neoliberal economic institutions that was neglected in earlier writing. It helps explain why some jurisdictions have lower crime rates (Piatkowska et al. 2020). Messner and Rosenfeld have shown a healthy humility about whether they got their list of institutions that are important to temper economic institutions right. We all do well to share in that humility as we join hands with them on their theoretical construction site.

Religious institutions and tax system integrity can temper the abuse of power. At some historical moments, abuse of the power of tax systems can drive domination, as we saw with the Boston Tea Party at the onset of the American Revolution and with Britain's colonial domination and destruction of India's flourishing precolonial economy by extractive tax 
policies alongside extractive environmental policies (tax Britannia and axe Britannia) (Braithwaite and D'Costa 2018: Ch. 5). At so many critical junctures, religious fundamentalism connects to militarism and business power to share in the domination of a society. In the trajectory of many wars, religious leaders have important roles as cheerleaders for aggression. For 23 of the 67 armed conflicts studied by Braithwaite and D'Costa (2018), religious leaders were both prominent in advocacy of violence at the early stages of the cascade to war and prominent in the advocacy of nonviolence at later stages, leading cascades to peace. ${ }^{2}$

Hence, theoretical humility also means that positivist projects of testing linear institutional effects cannot do all the work. Quantitative research must be complemented with a historical method that thinks in time about tipping points like those we revealed with religious leaders tipping from being major pro-violence to anti-violence actors. Institutions that once contributed to domination, violence, militarism and commodification frequently pass tipping points to a politics of nonviolence and nondomination. Nelson Mandela's biography manifests a shift from the leader who persuaded the African National Congress (ANC) to be a party of violent revolution in alliance with the Communist Party, to leading the ANC to be a party of peace and democracy that included whites. The most important things we must gradually learn to comprehend are tipping points from domination to freedom and how agonistic pluralism can be mobilised to the politics of tipping domination (Chapter 12, this volume; Mouffe 2013).

The next chapters argue that beyond institutions of taxation and religion, many more supplementary institutional checks and balances are needed for a low-crime, high-freedom society. In this respect, Messner and Rosenfeld and the empirical research they have stimulated have put us on the right path towards a pluralisation of the range of institutions for freedom. What the next chapter seeks to theorise is how to develop a strategy for taking their institutional pluralisation further and for thinking in time about that pluralisation. We should learn so much from the accomplishment of Messner and Rosenfeld in their first widenings of the scope of institutions considered in anomie theory and from the quantitative comparativists who followed in their footsteps.

2 This number is an update that includes some extra armed conflicts coded since Braithwaite and D'Costa (2018). 


\section{Evidence on inequality, crime and violence}

Evidence of the relationship between inequality, poverty and crime is important to the analysis in this book and to figuring the normative implications of institutional anomie theory. I deal with this evidence somewhat briefly because my review of evidence on institutional anomie theory incorporates so many studies of the inequality-crime, povertycrime, unemployment-crime, welfare-crime and even tax equality-crime relationships, particularly in Pratt and Cullen's (2005) and Nivette's (2011) meta-analyses, but also in so many studies since. The data on the relationship between inequality and crime discussed in this section measure overwhelmingly what are crimes of the powerless, such as individual homicides. To understand how inequality might also contribute to crimes of the powerful that are more effectively covered up (and almost impossible to count with reliability and validity), we will mainly rely on more ethnographic forms of data in the next chapter.

Braithwaite and D'Costa (2018: 519-33) juxtaposed some differences between the evidence of the relationship between inequality and crime and that between inequality and war. This is of note for the macro-frame of this book, which posits an important relationship between cascades of war and cascades of crime (Chapter 11). Braithwaite and D'Costa used their South Asian data as well to make new sense of the confusing state of the evidence on the relationships between poverty, inequality and different kinds of violence. They argued that continuous struggle to halve global poverty and inequality again and then again is important for a less violent world. Even though low GDP predicts war but not crime, and national inequality predicts crime but not war (in a lot of studies), Braithwaite and D'Costa's research shows why tackling poverty and inequality in a complex way at multiple levels might reduce both crime and war. Part of the integrated social justice strategy required involves making power accountable at many levels. These are the topics of the next few chapters, as are tackling domination and humiliation at the local and national levels and the level of global imaginaries and global institutions. Most importantly, policymakers can aim to join up these strands of a web of global and domestic pacification to form a progressively more resilient fabric of peace and prevention. 
Indonesia is a good example of a society that has performed quite well at the structural level in reducing poverty and in progressively becoming freer, democratising and delivering good outcomes in countering terrorism and violence. Only a small handful of developing economies have less inequality than Indonesia as measured by the Gini coefficient. Yet, the Peacebuilding Compared data (Braithwaite et al. 2010a) show that when a local ethnic or religious minority felt dominated by being excluded from a fair hearing over a land dispute, with political and legal institutions controlled by another group, 'small-town wars' resulted at the turn of the century (van Klinken 2007), and small-town wars cascaded from local domination to nationally militarised violence. Likewise, in Indonesia and Timor-Leste, abuse of power by tiny cabals of cronies with military connections is a form of domination at the very top that has recurrently ignited violence, notwithstanding Indonesia's creditable macro-equality (Braithwaite et al. 2010a, 2012). The Indonesian case study shows it is hard to temper the commodification of societies without tempering militarisation. Peacebuilding Compared data from Indonesia and TimorLeste show why we specify domination reduction more than inequality reduction, as a more insightful way of seeing what is required to tame violence. We conclude that brute structural remedies to inequality can only address some of the interactions among local, national and international imaginaries of domination and injustice.

Braithwaite and D'Costa (2018) argue that structurally more equal parts of the world enjoy less-criminalised states, less-criminalised militaries and local institutions and suffer less violence from both war and crime. Gender discrimination is a particularly important structural factor in explaining violence. Gendered domination generates violence, which engenders more gendered domination. Also important are inequalities between destitute landless people and their often-criminal landlords, between homeless Indigenous Australians and the European criminals who stole their land at the point of a gun, between poor people who pay tax and crony capitalists with western bankers who do not, and contextually endless other modalities of inequality. These structural inequalities demand structural remedies that grapple with the diverse character of such dominations, the most important of which are separations of powers to render governance more accountable to the disenfranchised-governance that can be criminalised by money politics or tyrannies of the majority (discussed in Chapter 8 of this book). Hence, Braithwaite and D'Costa's conclusion is that domination is the more fertile concept for explaining violence than 
inequality, with militarised domination and criminalised domination of governance particularly critical modalities of domination. Yet struggles against domination and discrimination must be contextually attuned and responsive to what are subjectively salient inequalities. Perceived racial discrimination explains crime. Being yelled at with racial slurs or insults is subjectively important in explaining crime (Unnever and Gabbidon 2011: 78-79). Discrimination tends to be perceived as highly salient and dominating when it is state sanctioned, which particularly strongly predicts civil war when it is extreme (Goldstone 2008: 5; Gurr 2000). Conversely, Saiya (2018) demonstrates empirically the capacity of what he calls 'religious liberty' to shut down state-sanctioned discrimination and thereby extinguish religious terrorism and religious violence. Fleming et al. (2020) found that where ethnic economic inequality is low, terrorism deaths are low.

Twenty years ago, few in the West would have seen humiliation and discrimination against Muslims as a major risk factor for violence that required a concerted antidiscrimination politics of inclusion, nationally and globally. The Allied powers were much quicker to learn from the geopolitical humiliation of Versailles that the right prescription for Germany, Austria, Italy and Japan in 1945 was a politics of inclusion (the Marshall Plan and the European Union).

Many heavily militarised societies that were infused with a politics of domination, corruption and extreme inequality in the twentieth century have become more egalitarian, less-dominating low-violence societies in recent decades, including Japan, Germany, Italy, Spain, South Korea and Taiwan. It is harder for highly militarised societies such as Russia, Pakistan or the United States, where violence and domination are less tempered (Krygier 2017) and less shameful (Braithwaite and D'Costa 2018), to deliver low levels of violence to their citizens. In societies like Congo, where men with guns can also monopolise money power, inequality became hard to conquer.

An inference from Braithwaite and D'Costa's (2018) data was that domination more richly and consistently explained violence than a thin conception of inequality measured by a national Gini coefficient. One way domination as unfreedom is thicker than inequality is that it better enables the integration of explanatory theory and normative theory (see Chapters 1 and 2 and Braithwaite and Pettit 2000). Yet thin inequality 
is an important constituent of thick domination. Hence, it remains valuable to consider the vast quantitative literature on the relationships between economic inequality, poverty, crime and war.

These bodies of literature are contradictory and confusing. At the individual level, people who are poor are much more likely to commit direct crimes of interpersonal violence such as assault, murder and rape, and common property crimes such as robbery, burglary and serious theft—an issue long debated between Braithwaite (1979) and Tittle et al. (1982). In that debate, my argument was that individual class effects on more serious crime were stronger than class effects on less serious forms of self-reported crime. I argued there was a danger of the variance in selfreported measures being dominated by the higher frequency of petty delinquency (such as stealing things worth less than \$5) and drug use. Petty delinquency and drug use were independent of general delinquency in Braithwaite and Law's (1978) factor analytic work on the structure of self-reported delinquency. Moreover, we found middle-class children were more concerned to conceal minor delinquency.

I had so much respect for Charles Tittle and his colleagues. The tensions over our contestation of the class and crime data remain a general tension over how we should read the literature, as we will see again in the paragraphs that follow for the literature on unemployment and crime. At the ecological level, different results are often found at neighbourhood, city, provincial, national and international levels. For those with a more positivist mindset, the tendency is to want to scan separately at each level of analysis and focus on the effect size in systematic reviews at that level. Usually there are inconsistent results. These are especially driven by the fact that domination-relevant variables can be and are measured in different ways that are positively correlated - the percentage poor, inequality, black-white inequality, unemployment, long-term unemployment, infant mortality, and more. We can and should respect the legitimate point of view of those who finger inconsistent results at each level of analysis to sow a criminology of doubt. At the same time, my argument is that we must stand back from that approach with a broader vision to see that just because sometimes there is no black-white inequality effect after controlling for general inequality, and sometimes there is no general inequality effect after controlling for black-white inequality, we do well to be reluctant to conclude that black-white inequality and general inequality have questionably inconsistent effects. Rather, we can read these data with a wider theoretical vision about how the kinds of 
inequality that are most dominating in different space-time contexts vary greatly. What is less invariable is that, when and where people are in the crosshairs of many intersecting forms of inequality, one or another of them risks becoming subjectively salient in ways that increase crime. Both the straight-counting positivist perspective and the open-textured macrotheory reading are valuable ways of seeing. Our job as criminologists is to be transparent about the ideology of data that leads us to favour one set of data over the other, and then leave it to the reader to make their judgement as to which synthesis is most insightful for them.

Consider again Nivette's (2011) systematic review of cross-national studies. One of her models finds inequality measured by the Gini coefficient is the strongest predictor of homicide across all studies. When a dummy variable for countries from Latin America and the Caribbean is added to the model, this becomes the strongest predictor and inequality becomes the second most important. Does this mean that inequality is not the most theoretically important predictor? Perhaps; perhaps not. We can take the view that the theoretically general thing in these data is inequality, and a central reason why Latin American countries have high homicide rates is that they have high inequality. This is also a central reason why the United States has a higher homicide rate than all other countries of high GDP per capita. Inequality is deeply structured in the Americas by histories of slavery, conflict over slavery and conflict over violent dispossession of the lands of indigenous peoples in unusually recent history. These dominations have also fed into highly racially politicised drug wars right across the Americas, which I have argued have criminogenic consequences. On this reading, inequality is seen as a measure of criminogenic domination, which remains the variable of greatest theoretical import. But there is another reading that says that the peoples of South and North America are culturally different in ways that make them more violent. There is a culture of violence that explains the patterns, which are stronger in some parts of the Americas than othersfor example, stronger in the southern states of the United States (Thomas et al. 2018). A third theoretical reading is that the peoples of the Americas are to varying degrees genetically different from those on the rest of the planet. There is more than a bit of politics in how people choose among these three possible readings of this evidence. That is why I like to be so explicit about my social democratic politics of freedom in attempting interpretative work. 
Unemployment may have a stronger impact on increasing the criminality of individuals with prior criminal records or with a propensity to crime than individuals who lack such predispositions (Aaltonen et al. 2013: 587). Short-term unemployment occurs for many reasons and does not have the impact of long-term unemployment on individuals' criminality (as found by Carlson and Michalowski 1997). Long-term unemployment has unusually strong explanatory power for violent crime (Nordin and Almén 2017). Much short-term unemployment reduces domination because it can mean that people quit oppressive, precarious jobs to find more satisfying work in empowering jobs that provide a long-term future. In some studies, a rise in short-term unemployment is associated with a reduction in crime; this may also occur for routine activity reasons such as improved guardianship of homes and children when adults are not at work (Pratt and Cullen 2005: 59). Bell et al. (2018) found evidence of longterm scarring and resultant crime for young people entering job markets during recessions; some are forced into employment in unrewarding jobs that are a poor match to their skills; for others, the experience of longterm unemployment at the beginning of their adulthood leaves long-term scars. Chapman et al. (2002) found that long-term unemployment for young men is the kind that has the largest impact on crime rates, as did Pratt and Cullen (2005) in their meta-analysis. The long-term impact that matters is whole generations who are truly disadvantaged, year after year from a young age, left without hope, giving up on their own future and that of their children.

Time-series studies of the impact of unemployment on crime continue to have the somewhat inconsistent results identified in my earlier work, though the inconsistencies are being clarified (Braithwaite 1979; Kapuscinski et al. 1998; Carmichael and Ward 2001; Edmark 2005; Alves et al. 2018; Costantini et al. 2018; Hazra and Cui 2018; Jawadi et al. 2021; Mittal et al. 2019). The effects of unemployment on property crime are often stronger (Aaltonen et al. 2013). Using US time-series data, Lin (2008) concluded that ordinary least squares (OLS) analyses have underestimated the impact of unemployment on crime because of endogeneity effects. He finds OLS to estimate that a 1 percentage point increase in the unemployment rate increases the crime rate only by 1.8 per cent; but the increase is 4 per cent with a two-stage least squares (2SLS) method. Of strategic importance was Lin's (2008) finding that during the decade when the great US crime rise flipped to the great US crime drop (the 1990s), after accounting for endogeneity, unemployment rates explained 30 per cent of changes in property crime rates in this era. 
Some of the best recent economic modelling of the complexity of endogeneity concludes that because crime increases unemployment as well as unemployment increasing crime and inequality, different neighbourhoods end up with radically different unemployment-crimeinequality equilibriums from identical starting points (Burdett et al. 2003). Falk et al.'s (2011) result that high unemployment contexts specifically increase right-wing extremist crime is an important one for the contemporary politics of domination. Chapman et al. (2002) found that the intersections between long-term youth unemployment and high school completion are critical to the explanation of high crime rates. Like the effect of participation in war on subsequent crime, deciding what is the right lag is difficult when most people who lose jobs are beyond the age of maximum crime risk while their children may be in that age group or about to enter it. The interaction between unemployment and welfare institutions is also critical to how lags work because crime does spike with a delay that kicks in after unemployment benefits expire following layoffs (Bennett and Ouazad 2020).

Most studies that compare census tracts of cities, whole cities, counties, states or standard metropolitan statistical areas find that districts and cities with higher levels of poverty or income inequality have higher crime rates (Braithwaite 1979; Chamberlain and Hipp 2015; Cheong and Wu 2015; Hsieh and Pugh 1993; Pratt and Cullen 2005; Scorzafave and Soares 2009). The effects of poverty were somewhat more consistent than the inequality effects on homicide in 47 studies analysed by Pridemore (2011: 752-53), while Nivette (2011) found that inequality was a strong predictor (see also Lappi-Seppälä and Lehti 2014). Time-series results on the impact on crime of changes in the level of inequality, poverty or unemployment have always been more inconsistent than data on individual poverty or ecological inequality cross-sectionally (see Brush 2007).

With property crime, class-related opportunity structures again complicate the picture as studies move from the individual level of analysis to ecological analysis. The richer opportunities in wealthy areas for crimes such as burglary and car theft have some effect in driving up rates in wealthy areas. Poor people who live close to rich areas commit more property crime than other poor people. Poor areas adjacent to rich areas have higher property crime rates than poor areas far from wealthy census tracts (Boggs 1965; Chamberlain and Hipp 2015; more generally on the spatial mobility of offenders, see Eck and Weisburd 2015: 17). When we aggregate to the societal level, statistical comparisons of national property 
crime rates have limited meaning because some police forces are more efficient than others at recording petty property crimes (and the more common petty crimes drive the numbers, not serious crime that is more infrequent). Also, in different legal systems, 'burglary', 'break and enter', 'break without entering' and 'entering without breaking in' can mean different things. ${ }^{3}$

With homicide rates, reasonably meaningful comparisons are possible, however, because it is hard for police forces to fail to record a body that turns up with a knife in its back. Homicide is also measured imperfectly but it has reasonably similar meanings cross-nationally. On the other hand, officially measured homicide rates tend to undercount homicide in the countries where it is worst and most militarised, as Braithwaite and D'Costa (2018) discussed in relation to the Peacebuilding Compared data failure for El Salvador to count disappearances as homicides. The society that had the highest homicide rate in the world at the time of writing was massively undercounting disappearances as something other than homicide. With homicide, high income inequality is consistently associated with high homicide rates (Braithwaite and Braithwaite 1980; Fajnzylber et al. 2000; Hsieh and Pugh 1993; Nivette 2011; but see Pare and Felson 2014; ${ }^{4}$ Pridemore 2011). ${ }^{5}$ Evidence of low-income countries having more crime than others has historically been inconsistent, although in recent decades it has become quite a consistent pattern that the highincome societies of Western Europe and East Asia have extremely low homicide rates (Chapter 3). Countries with a wide gap between the rich and the poor (or countries with a high Gini coefficient for income inequality) very consistently have higher homicide rates. While poverty is the better predictor of crime than inequality in subnational ecological analyses, and inequality is a better predictor than poverty in international

3 When survey data are collected consistently across a large number of countries, as in Elgar et al.'s (2009) finding of a correlation of 0.62 between income inequality and rates of bullying in 37 countries, we can take an interest in the possibility that inequality is conducive to societal cultures of bullying. We should also be cautious, however, that the bullying measure might mean rather different things in translation among different tongues and societal contexts. In most, however, bullying has a meaning close to our conception of domination.

4 Pare and Felson (2014) found both strong inequality and strong poverty effects in increasing crime at the cross-national level. However, inequality effects disappeared after controlling for poverty. 5 Pridemore (2011) compares 47 studies to show that income inequality is consistently associated with higher homicide rates cross-nationally, but not as consistently as poverty. His analyses further show that such relationships always remain if GDP per capita is included in the model. Most interestingly, he finds in a number of studies that, when child mortality is included in the model, the income inequality effect disappears. 
comparisons (but see Pridemore 2011), both massive literatures have many crossover studies that show the reverse, more that show that both are important and a few studies that show that no measures of poverty or inequality matter. Generally, one or more of these effects persists even after significant impacts of racial inequality on crime are controlled for.

The next chapter argues that at the societal level the complication caused by the organisational crimes of the rich might be elegantly resolved. In radically unequal societies, the rich tend to enjoy unaccountable power, while the poor are desperately powerless. A narrow elite puts in place extractive political institutions that concentrate power in their hands; they disable constraints on the exercise of that power. This in turn allows the elite to put in place extractive economic institutions that exploit the rest of society (Acemoglu and Robinson 2012). Put another way, the institutional economics of Acemoglu and Robinson's Why Nations Fail, and the now considerable empirical support it enjoys, means that the criminalisation of states by elites creates the conditions for institutional anomie explanations to be true. When inclusive institutions are rejected in favour of extractive institutionalism, institutional anomie and high crime rates follow. Inclusive institutions on Acemoglu and Robinson's account are the key to lifting failing nations to prosperity. Being lifted out of the 'bottom billion' is a protective factor against civil war and the crime that cascades because of war (Braithwaite and D'Costa 2018; Chapter 11 of this book).

Political institutions that concentrate power for the few and exclude the many do not prioritise quality public education, health and welfare systems for the many, particularly not for excluded groups who are disfavoured by the rulers. Macro-institutional mechanisms that conduce to the criminal society and the criminalised state are therefore shared between institutional anomie and the economic institutionalism of Acemoglu and Robinson. The extractive institutions of a criminalised state by definition allow the elite to exploit all those excluded from elite networks. This plays into the analysis of future chapters that crimes of the powerful are expropriative and exploitative, while crimes of the powerless are crimes of the exploited. The exploited make the best of a bad job while the exploiters take advantage of a good job enabled by the lure of extractive institutions. 
More broadly, the work of many of the most influential scholars of the politics of development connects in a non-criminological way to Cloward and Ohlin's criminological insights on the lure of illegitimate opportunities and Messner and Rosenfeld's on the preventive power of plural and inclusive institutions. I do not assert that the political economy scholars discussed above accept my interpretation of their common ground with institutional anomie theorists. Nor do I suggest that either group accepts my interpretation of the intersections between their theories and what they imply for the politics of inequality. I do hope, however, that finer-grained delineation of the separation of powers needed to temper concentrated power makes that interpretation more credible in the next two chapters.

Commanders of criminalised states strip away the institutions that might limit their opportunities by, for example, arresting or firing anticorruption commissioners or judges. Samuel Huntington's $(1991,2006)$ work is fundamentally about how the corrosion or absence of institutions explains instability and violence (likewise Francis Fukuyama’s 2014 research). Criminalisation of the state conduces to what Michael Mann (1986, 1993) calls despotic power: the capacity to suppress dissent, rights, the media and opposition parties. Despotic power gives states the appearance of strength. More effective state strength comes from what Mann calls infrastructural power: the power to secure public safety by legitimately making and enforcing laws, and the power to deliver peaceful growth through infrastructures of education, health and other public goods. For Acemoglu and Robinson (2012), criminalised states crush peaceful development because they are extractive, pushing aside the inclusive institutions that enable peaceful development. In Douglass North et al.'s (2009) Violence and Social Orders, mafias and other organised criminal groups that strip state assets are examples of 'limited-access orders' wherein a coalition of rent-seeking elites deploys political power to prevent both political and economic competition. For North et al. (2009), violence and poverty are endemic in criminalised states because institutionally they are limited-access orders. Merton might approve of this interpretation of their comparative data.

The powerful are also able to buy their way out of trouble with the law, while the poor are denied access to justice in radically unequal societies. Hegemony and the purchase of impunity create profound opportunities for crimes of the powerful; the degradation, hopelessness, loss of identity and meaning of the poor foster crimes of the powerless. Hence, unequal 
societies have both more crimes of the powerless, because the powerless are exploited, and more crimes of the powerful, because the powerful exploit. This argument is developed with institutional detail in the chapters that follow.

\section{Poverty versus inequality; war versus crime}

The quantitative literature on civil war, GDP per capita and income inequality seems at first glance to paint a somewhat opposite picture to that for crime. It is poverty conceived as national GDP per capita that predicts war, not inequality between rich and poor-the top explanation of homicide rates in Nivette's (2011) meta-analysis after controlling for the Latin American dummy (as confirmed by Schargrodsky amd Freira 2021). 'The bottom billion' in GDP per capita are at profoundly greater risk of civil war. Moreover, Collier (2007: 19-20) summarises the literature as clearly showing that poverty contributes to war, and war (or the anticipation of war) contributes to disinvestment and poverty. Wars also last longer in low-income countries (Collier 2007: 26). Fearon and Laitin (2003), furthermore, found that low GDP per capita and weak institutions were associated with the onset of civil war, but they argued that GDP may be a proxy for weak institutions. ${ }^{6}$ This insight might be reinterpreted in institutional anomie terms. In most studies, countries with high income inequality do not have higher risks of war, although Collier et al. (2004) found that conflicts in unequal societies lasted longer than elsewhere.

When we move down to the village level, as in Nepal et al.'s (2011) study of 3,857 Nepalese villages, villages/districts with a wide gap between landlords and the landless do have higher rates of war deaths. Systematic qualitative comparisons of dozens of rural Indian districts that have and have not experienced Maoist uprisings likewise conclude that locally unequal development is the key variable (for example, Chakrabarty and Kujur 2009), as opposed to national inequalities. Local dominations are critical to decisions to join civil wars in village societies. Rome is far away, and most poor people do not know or care much about the politics of

6 The frequency with which infant mortality emerges as a considerably stronger predictor than GDP per capita of the probability of civil war recurrence (for example, Quinn et al. 2007: 187) might mean that infant mortality is an even better proxy for weak governance institutions. 
the capital. Most critically, mobilisation is local rather than national in terms of putting together armed units that are motivated to take and hold a district. Armed gangs cannot recruit and mobilise if grievances are only national and do not cut through as local grievances. As illustrated by the rise of the Nepalese Maoists and the Taliban from very local injustices, as diagnosed by Braithwaite and D'Costa (2018), once a local armed group pacifies a remote niche, this can become a base for building bigger ambitions and wider imaginaries, as victories expand the opportunities for power and plunder, and alliances are forged with other armed groups in control of other districts. Grievances over national inequalities are not as critical to this process as the aggregation of grievances over disparate, distinctive, local inequalities.

This perspective helps account for why Philip Verwimp (2005) found that poor and tenant farmers were overrepresented among génocidaires, while landlords were disproportionately victims. Poverty and promises of wealth were associated with recruitment to rebel armies in Sierra Leone (Humphreys and Weinstein 2008). Catherine Riordan points to this research and other data to suggest a conclusion for the inequality-war relationship similar to Braithwaite's (1979) about the inequality-crime relationship:

Recent findings indicate that in societies characterized by greater levels of inequality, members of both wealthy and poor ethnic groups are more likely to be involved than those whose income is near the national average (Cederman, Weidmann and Gleditsch 2011). This could be explained by the engagement of the wealthy in conflict to defend their property, and the engagement of the poor in order to increase their wealth; or as a synergistic product of inequality: poor people increasingly participate in conflict as they become poorer, and wealthy people have more to contribute financially to conflict as they become wealthier, meaning that greater inequality drives greater participation into conflict (Esteban and Ray 2011). (Riordan 2013: 35)

Riordan's interpretation of the data goes to the often-heard rebuttal of the claim that terrorists are disproportionately poor by reference to the wealth of the likes of Osama bin Laden. Yes, top terror leaders may be disproportionately wealthy exploiters. The suicide bombers and foot soldiers, however, are disproportionately poor, manipulated and exploited. The inequality-war relationship is complicated by the fact that fighting an uprising requires the organisational capacity to mobilise many 
fighters and to buy credible weaponry. In this business, the rich have more organisational capacity (to enrol and coopt foot soldiers) than the poor, and greater buying power for weapons and wages. Poverty and injustice do not cause war unless poor people with a grievance can connect with wealthy benefactors who fund the logistics of feeding and arming troops. Barrington Moore (1966) reached the conclusion that landless peasants are unlikely to rise against their domination unless some external power takes their side against the power that oppresses them. Insurgencies of the disenfranchised do not scale up to winning wars without external sponsors. Indigenous defenders of the Australian continent did not inflict major defeats on white land thieves because no external power, wealthy benefactor or diaspora was supplying them with arms. For the comparatively poor Taliban fighters of Kandahar in 1994, these financial backers initially were the Quetta trucking mafia who were fed up with being shaken down in this lawless zone; later, Pakistan's intelligence services funded the Taliban. Later still, the destitute Taliban fighters of Peshawar's refugee camps were supported by the wealth of Persian Gulf funders like Osama bin Laden, and later still many overcame their resistance to the opium trade and used opium sales to fund their war (Braithwaite and D’Costa 2018: Chs 6 and 9).

Riordan (2013) contends that as a long-deprived group in a society becomes better off, it has better means to engage in conflict (Besançon 2005). Consistent with Nepal et al. (2011), Riordan (2013: 35) then contrasts local with national inequality effects:

When examined at the micro-level, however, areas of countries which had more absolute poverty were more prone to outbreaks of conflict, suggesting that inequality increased the risk of conflict (Buhaug et al. 2011; see also Buhaug and Rød 2006). It seems that not only does inequality play a role in the incidence of conflict, conflict itself further exacerbates economic inequality, although this effect diminishes over time and inequality typically returns to pre-war levels within five years after conflict ends. (Bircan, Brück and Vothknecht 2010)

The capacity and opportunity to mobilise against governments and to have complaints listened to reduce armed violence, as does the absence of state-led discrimination (Braithwaite et al. 2010a; Cederman et al. 2011; Fearon and Laitin 2000, 2003; Goldstone 2008: 5; Gurr 1993, 2000; Linder and Bächtiger 2005; Rørbæk and Knudsen 2015; Wimmer et al. 2009). The power of these state-led discrimination effects is one reason 
state-sanctioned slavery might be fundamental to understanding both long-run global patterns of violence and even contemporary patterns. The World Development Report (World Bank 2017: 8-9, 119) has taken up this theme, showing that societies with more even internal balances of power have better national security with less violence. We can interpret this considerable body of studies in different ways as measuring the positive impact of inequality of political power on armed violence, as opposed to inequality of wealth, although these different forms of inequality are themselves correlated.

Cramer and Richards (2011) have made a fine contribution on the risks of being seduced by surface appearances created by quantitative studies of the relationship between inequality and civil war. They explain how the terrible levels of rape, murder and amputations in Sierra Leone's civil war have been advanced by quantitative scholars as being more about greed than grievance and inequality. Specifically, greed for conflict diamonds was important in that war, and in the quantitative literature. Cramer and Richards (2011: 278) conclude that this 'poster child for "greed not grievance" theories' was a 'product of systematic exploitation of the countryside' and 'fed off rural impoverishment and despair'. It was a peasant revolt with agrarian roots against the way urban produce and marketing boards, currency speculators and cronies of the state made peasant land tenure insecure, collapsed state welfare in rural areas and redistributed wealth from peasants to urban powerholders to the point of driving deep resentments over rural-urban inequalities. Researchers cannot grasp the texture of such case-specific inequalities without getting their boots wet. Gender inequality was also tragically in play, as the subsequent rape conviction of President Charles Taylor at the International Criminal Court demonstrated in 2012. The conviction was based on a rich mix of qualitative and quantitative data on patterns of rape. If researchers just pore over the tables of quantitative studies, valuable as that is, their work can miss the mark, as in the Sierra Leone case.

\section{Evidence on gender inequality and violence}

Positive associations of different kinds of domination are the core of the theory of intersectionality in feminist theory (Crenshaw 2017; Cooper 2015; Henne and Troshynski 2013). The theory of intersectionality is 
about the idea that while different forms of domination-for example, domination based on race and gender-are distinctive, diverse dominations intersect to reinforce one dimension of domination with another. Societies in which gender-based violence is normal in families are more likely to engage in militarism and war than societies with lower levels of gender-based violence (Cockburn 2001; Erchak 1994; Erchak and Rosenfeld 1994; Levinson 1989; see also Caprioli 2005; Hudson et al. 2009, 2012). One interpretation of this is that boys and young men learn in families that they can get their way through violence. This lived reinforcement of violence then generalises to how they conduct themselves as men in the community and in international affairs (Patterson 2008). Quantitatively, societies with high gender inequality are more likely to experience deployment of military power in conflicts (Caprioli 2000, 2003; Caprioli and Boyer 2001; Caprioli and Trumbore 2006; Hudson et al. 2009, 2012; Melander 2005; Sobek et al. 2006). In a variety of ways, Hudson et al. (2009, 2012: Ch. 4) have shown that states are more likely to enjoy security when the women who live in them enjoy security from domination. The evidence is consistent with the interpretation that gender inequality in a society grows sexual and gender-based violence and this increases the prospects of violence in the national and international politics of that society. Moreover, Braithwaite and D'Costa (2018) showed that across South Asia, war has increased sexual and genderbased violence during and after conflict. There is a recursivity that reinforces cycles of gender inequality, violence against women and war, and then further increases in violence against women. The macro-shift in the history of civilisations here may have been the proliferation of the professionalisation of militaries that came with the blades of the Bronze Age. Feminised elites were more common until gender partnership was displaced by militarised domination in the Bronze Age (Eisler 1987; Min 1995). Men were not kept close to home by childbearing in the years of their peak physical powers, so men were the ones who roamed far in murderous cavalry units and navies. The militarisation of societies structurally mediates the recursiveness of violence engendering inequality and inequality engendering violence (Braithwaite and D'Costa 2018).

Intrasocietal violence against women is driven by an unequal politics of domination and humiliation in a way that helps us understand how violent patriarchy at home might promote armed violence against women abroad. The next chapter discusses how humiliation can motivate violence among those humiliated and enables violence among those who humiliate. 
Heirigs and Moore (2018) confirm that, after controlling for the Gini coefficient (and other variables), higher gender inequality is associated with higher homicide rates cross-nationally. Narvey et al. (2021) also found that women's economic equality, economic empowerment and legal rights were associated with lower homicide rates cross-nationally.

One reason exploited poor people find it hard to organise nationally for the violent overthrow of the state is that a society's poorest people are often a minority. Consider the invasions of the continents of North America and Australia by comparatively rich people from Europe. The invaders quickly became organised in states such as Massachusetts and Virginia and then in federal states - the United States of America, Canada and Australia - militarised with the most modern technologies for killing. Aboriginal Australians and Native Americans could give the first settlers a tough time in pushing back their invasion but, as soon as European numbers grew and mounted troops followed, genocide diffused and resistance collapsed. Aboriginal Australians did not have the resources or the national organisational capabilities to unify sufficiently to fight a credible war against the white state. Local grievances often triggered local uprisings, which created opportunities to 'teach blacks a lesson'. But once Indigenous Australians were stripped of the land that was the source of their wealth, once their population fell to less than 3 per cent of the population of their colonised country - an impoverished, dispersed 3 per cent without the resources to buy the guns to take on the superior firepower of the colonisers-civil war became unthinkable for them.

Hence, the deepest structural inequalities in the world, such as those that Aboriginal and Torres Strait Islander Australians continue to suffer, rarely lead to civil war. That is one important reason the statistical association between national inequalities and war is inconsistent. Inequality drives high crime rates in a different way, however. Aboriginal Australians committed murder and were victims of murder at seven to eight times the rate of the general population between 1989 and 2000 (Mouzos 2001). Their overrepresentation in the prison system is twice as bad again. Indigenous Australians continue to this day to be disproportionately victims of state crime such as police violence. They are impoverished peoples whose identity and sense of meaning have been decimated, who have often lost hope for themselves and who struggle to pass on hope to their children, who therefore enjoy few legitimate opportunities. 
Women are not a minority. Nevertheless, wars are rarely fought to reverse the domination of women. An ethnic, religious or political minority of just 20 per cent of a national population can, ironically, more readily concentrate its 20 per cent in particular regions where it controls local political parties and local resources for war fighting in that locale if, for example, it is 80 per cent of the population in that locale. Women may be 51 per cent of the population, but they will also be around 51 per cent in enemy territory. Concentration is more difficult. Freeing up women from obligations tied to childbirth in the peak years of kill-before-beingkilled war-fighting capability (18-30 years of age) is difficult. Fighting for equality through civil war is not something women can easily concentrate womanpower to do, even if they want to transact their politics violently, which most do not. A feminist leader with the ideology of Frantz Fanon (1965) on the cleansing power of violence against male oppressors seems implausible and unthinkable to women who lead. Gendered inequality is the deeply structured inequality that most consistently fails to cause war. It also fails to then cascade from war to postwar domestic violence by women.

That is not to diminish some remarkable pacifications and transformations that have been accomplished by female fighters in local contexts such as in Rolpa at the heart of Nepal's Maoist insurgency. In that case, however, the transformation of domination was accomplished by transforming the conflict, Mandela-style, from an armed struggle to a people-power nonviolent uprising on the streets of the capital in 2006 (Braithwaite 2015; Braithwaite and D'Costa 2018).

The ending of the Yazidi genocide in Sinjar, Iraq, on the other hand, was totally accomplished by armed force. Brave Kurdish and Yazidi women interviewed in Iraq and Iran during Peacebuilding Compared fieldwork surged to the frontline of the fight to stop the rape and genocide. Most of the Kurdish female fighters were from Syria and Turkey, but many were also from Iraq and Iran. Their commander showed me their horrific training video for how female fighters must kill themselves quickly because 'girls must not allow themselves to be captured by Islamic State'. I wept tears of shame at the thought that western fighters, including from my country, had started this cascade of violence in Iraq that became a genocide in Sinjar. Now we were asking these young female fighters to do what we were unwilling to ask Australian fighters to do at the frontline, though Australian flyers did fight Islamic State from the air. The Australian people would not have tolerated sending our female fighters into house-to-house 
combat with Islamic State with instructions on killing themselves rather than surrendering as a prisoner of war. And so I wept again with a complex kind of shame at the circle of Kurdish and Yazidi women singing a song of courage in the dark around the fire before joining the frontline combat.

For me, this was partly shame in complicity in what later became a more total betrayal of Kurdish allies by President Trump. These Kurdish fighters, perhaps as many as 25,000 of whom were women (Khezri 2019), had done most of the house-to-house combat against Islamic State in Syria. More than 10,000 Kurdish fighters lost their lives, perhaps 1,000 of them women, as 30 per cent of the Kurds who fought Islamic State in Syria were women (Lemmon 2021). Certainly, many times more Kurdish women lost their lives fighting Islamic State (and Al-Qaeda) than the less than 100 Western warriors who gave their lives in these battles from 2014.

Around the fire, these brave young women encouraged one another to taunt the Islamic State fighters that there would be no virgins in heaven for men killed by women. Many Islamic State fighters did indeed believe this was a path to shame rather than martyrdom. That was one reason women were wanted by commanders at the very frontline in the hope of causing desertions, shattering Islamic State morale. These women's sacrifices contributed greatly to ending a genocide. The West does not even speak of the Yazidi genocide in the way it speaks of other admittedly larger genocides. Coming to terms with shame for those we fail to save from the worst dominations of violence is something the West must get better at. It is a crucial step towards learning how to prevent cascades of crime and war before they accelerate to genocide. That is a central focus of Cascades of Violence (Braithwaite and D'Costa 2018).

Like Nepal's feminist Maoists, the Kurdish feminists insisted on inspiring the institutionalisation of grassroots political empowerment of women in the areas liberated from Islamic State through the Charter of the Social Contract, the constitutional law for the local councils of northeastern Syria. It guaranteed 40 per cent women's representation in legislative and 'all governing bodies, institutions and committees' (Lemmon 2021: 61). This empowerment was disrupted when the Turkish military advanced against those Kurds who liberated us all from Islamic State (Khezri 2019). 


\section{Domination as a specification}

Domination and inequality are highly correlated phenomena. The inductive theoretical conclusion of Braithwaite and D'Costa (2018) is that domination is a better specification than inequality to explain civil war. We can focus on domination within Kalyvas's (2003) model of local cleavages that interact with supralocal structural inequalities. As in Nepal et al.'s (2011) data, because mobilisation against grievances is local, village dominations can give rise to the mobilisation of local armed groups, especially if supralocal linkages enable local access to the organisational and financial capacities for army formation. Chairman Mao understood this. It is why Maoist strategy was about building rural armed groups around the local grievances of the most immiserated peasants, who were most dominated by their landlords. Then Maoists spread this strategy from hotspot to hotspot until, ultimately, these village struggles connected up. An armed countryside ultimately surrounds the capital. Braithwaite and D'Costa's (2018) empirical conclusion is that dozens of Maoist struggles, mostly in quite remote regions of South Asia, continue today to successfully exploit local grievances and cause local killing. They are not so successful at connecting up across a whole country today (except in Nepal until 2006) and not so successful today in spreading a Maoist imaginary.

Braithwaite and D'Costa (2018) also explored the rise of very different kinds of grievances over local dominations, typified by the rise of the Taliban. Local jihadist groups might derive their sense of domination from the militarised oppression and exclusionary practices they experience in their corner of the Kashmir Valley, the Swat Valley, Iraq or Libya. But, as with Maoism, their sense of local grievance is connected to a global imaginary (about jihad and against oppression by western infidels and their eastern dupes). Peacebuilding Compared found that refugee camps and the madrassas near them funded by jihadists are critical local sites for allying resentment over the local experience of domination with global cleavages, with a global domination imaginary and with global crowdsourcing from rich sponsors.

This is another sense in which national inequality is not the best specification with which to approach domination. Why is national inequality not the best way to see the effects of domination that explain terrorism? Why is domination at the local level (which intersects with 
more global imaginaries of domination) the more pressing imperative for the prevention of civil war and terrorism? The domination of being a Palestinian refugee in Lebanon or Syria with no job, no home, no right to return home, no country, no access to education and subject to targeting and systematic murder by foreign armies illustrates why. In Peshawar, Al-Qaeda proved more adept at fixing those dominations than the UN High Commissioner for Refugees and western humanitarian NGOs (see Braithwaite and D'Costa 2018: Box 9.2). In addition, the global domination of Muslims must be addressed. It is just as hard to reverse the colonial occupation of Arab lands by the West from World War I or the humiliation of the Mughal Empire by the British army in the previous century, as it is to reverse the European decimation of Aboriginal Australia or the indigenous nations of South Africa. Yet Apartheid can be dismantled and discrimination against Aboriginal Australians and Aboriginal land rights can be tackled-for example, through achieving Australia's initial 'closing the gap' targets and then empowering Indigenous people to choose how to broaden and tweak those targets. Likewise, discrimination against Arabs in Israel can be confronted, Palestinian land rights can be addressed with justice, Palestinian refugees can be given the right to return to their homeland, the bombing of Gaza's economic infrastructure can end and cutting off its economy from global markets (which delivers Gaza a 43 per cent unemployment rate) can end. In South Asia, Muslim Kashmiris can be given an active voice in shaping a permanent peace settlement for Kashmir that they view as fair in all the circumstances, against the background of the complex of geopolitical realities that confronts their valley.

An important recursive relationship here is, first, that state-based discrimination, particularly as measured in the Polity dataset, is associated with higher armed conflict (Akbaba and Taydas 2011; Cederman et al. 2011; Gurr 1993, 2000; Regan and Norton 2005; Wimmer et al. 2009; but see Jakobsen and De Soysa 2009). Vadlamannati (2011) has confirmed Gurr's (1970) Why Men Rebel conclusion on quantitative data across nine north-eastern Indian states. Vadlamannati found that poverty (compared with the rest of India) and economic and political discrimination explained outbreaks of violent conflict after controlling for income, population pressures, state capacity, ethnic affiliations, the amount of forest area, years of peace, neighbouring conflict incidence and distance to New Delhi. Furthermore, Rodrik (2000: 25), using the Polity dataset, showed that the ability of non-elites to access political institutions 
increases national economic growth. In other words, while national income equality might not consistently predict reduced armed conflict directly, poverty reduction might, and the nondiscriminatory access of non-elites to political institutions predicts poverty reduction.

An important conclusion about the tendency for different kinds of inequality or discrimination to be inconsistently important to freedom and crime in different contexts is to be wary of selective positivism. After failing to find a particular linear effect at a particular place and time, selective positivism should not drive a renunciation of domination effects. Because it is hard to predict when particular dominations will fuel raging fires of subjective oppression and violence, and when they will not, societies do well to aim at tempering all kinds of domination.

\section{Domination, humiliation and reconciling violence}

The exploitation of Muslim societies by western oil magnates backed by colonial gunboat diplomacy has already receded. However, Muslims still experience so many other forms of humiliation and stigma in and by the West. Some westerners consider insulting the prophet Mohammed a show of pride in the exercise of their freedom of speech. Some politicians can see the humiliation of Muslims as paving a path to power. Some westerners view 'banning the burqa' as a secular security policy that applies equally to all, as a measure to liberate women and not as a policy of religious discrimination. Global dominations must be connected to the observation that most of the dominations local Muslims feel have a local character. In Sydney, resentment over racism towards 'Lebs' (Lebanese) had been palpable in restorative justice conferences over incidents of racial and religious abuse in local high schools years in advance of the 2005 Cronulla riots between 'Aussies' and 'Lebs'. Local restorative justice over local dominations in high schools, refugee detention centres, prisons, workplaces and rural towns is a way that countries such as Australia can struggle against these dominations that can lead some young Muslims beyond rioting with rocks to suicide attacks and to Islamic State.

That is also a reason restorative reconciliation committee work in the areas of Pakistan bordering Afghanistan is important. As Braithwaite and Gohar (2014) argue, the reconciliation committees matter because they 
help prevent the cascading of civil war by resolving local dominations and humiliations and restoring order to areas where a collapse of the capacity to regulate violence gives the Taliban a foothold. My fieldwork experience of these reconciliation committees sees them as rituals of anomie reduction, humiliation reduction and revenge reduction. For children who have been dealt a wretched hand in a refugee camp, as a survivor of a family wiped out by a drone attack, reconciliation rituals must also do better at offering placement into a high-quality education, excellent vocational training and job placement into an economy that pays decent wages to people from impoverished backgrounds. The integration of economic justice and restorative justice is difficult but achievable. For the rape victims of Rolpa (Nepal), the integration of restorative forms of justice and economic justice in the people's courts was critical (Braithwaite 2015). Halving national gender inequality or the national Gini coefficient on its own is unlikely to have much effect on the probability of further civil wars. The powerful linkage is to harness national equality policies to local reconciliation that heals local hurts, restores local dignity, repairs local harms and reverses local discrimination against the poor and excluded. This can reduce local crime, as well as local armed conflict, and the way they cascade one into the other. On this analysis, the healing of cleavages with an integrated local-national strategy might make a difference. Micro-macro methods lead us to see the interaction between local, national and international imaginaries of domination and injustice as needing a reparative policy yeast for the bread of positive peace to rise. That is why brute structural remedies to national injustice cannot do the job in isolation.

Let me, then, be more specific about the hypotheses Braithwaite and D'Costa (2018) induced from these various data. National inequality reduction on its own bears a weak relationship to reduced prospects of war. National inequality reduction coupled with local inequality reduction, however, contributes to effectiveness in peacebuilding that reduces the prospects of war. Combining global reductions in inequality with addressing global imaginaries of domination and with national and local reduction of inequality can, even more strongly, reduce the incidence of war and crime on the planet. Reducing gender inequality at all levels seems particularly strategic, as does reducing racial inequality and religious discrimination. These seem to be the conclusions most consistent with the current state of the diverse kinds of evidence on inequality, crime and war. Because high crime rates, criminalised states and criminalised markets are 
forms of disorder that often spark wars, and because inequality increases the risks of crime, inequality reduction can also reduce the risks of war through this indirect path.

National income inequalities between Muslims and non-Muslims therefore matter, even if local and global dominations and humiliations seem in Braithwaite and D'Costa's (2018) data to matter more. Having individual young Muslims being economically marginalised, unemployed or treated unjustly by the police renders them more vulnerable to terrorism (Fleming et al. 2020), just as it leaves them more vulnerable to all other forms of violent crime. Muslims who experience these things are more susceptible to recruitment to violence in the same way as non-Muslim young people who experience them are susceptible to crime. Reducing poverty helps - and that is certainly a challenge of national policies. Yet very few young Muslims who experience the extreme poverty of refugee camps become suicide bombers. Even so, a society that lifts its young people out of poverty can have less crime and chaos on its streets and fewer people who are susceptible to recruitment to violent jihad in prison, in refugee camps or in front of their internet screens. Jihadist strategists learned the lesson that poor children who need an education, or bereft refugees, are good targets. They learned that rural anomie enables the seizure of local power. So why cannot those who work against their violence give priority to fixing these same dominations?

Changing tack, one critical reason that states with low GDP per capita have recurrent civil wars is that poor states cannot afford good state institutions, especially the accountability and welfare institutions discussed in the next few chapters. Extremely poor societies have not even learnt how to build them. As a result, the state often falls prey to criminalisation. Ultimately, ambitious alternative leaders seize opportunities to use armed force to overthrow the criminals who strip state assets. Sadly, the successors are often warlords who have the ruthlessness and resources to organise armies. Usually, their ambition is a renewed criminalisation of the state to their benefit. Hence, a fundamental way to prevent war is to help states grow out of poverty and grow their institutions. This is also Collier's (2007) empirically grounded prescription about 'the bottom billion'.

In sum, even though low GDP predicts war but less so crime, and national inequality predicts crime but less so war, both crime and war can be reduced in the long run by consistent application to tackling poverty and inequality in an integrated way at all levels. Braithwaite and 
D'Costa (2018) showed, for Nepal and Indonesia, for example, that it is hard to predict whether it will be inequality at a very local level, a regional level, a national level or global inequalities between Muslims and Judaeo-Christians, caste inequalities, racial inequalities or some other identity politics that will mobilise grievance or violence. Albert Cohen alerted us to the possibility that inequality at the level of the school can mobilise grievance, subculture formation and violence. Any one study that compares high with low inequality at just one of these levels of analysis neglects the possible sources of crime and violence at all the other levels of analysis.

In Mertonian terms, at most levels of analysis, at most historical moments, the inequality at that level may not tap into a salient frame of aspirational reference. Most Christians may not care or even know whether Muslims are richer or poorer than them; Nepalese peasants may not aspire to be as wealthy as landlords and may accept their poverty without grievance or anger; the Colombian underclass may be reconciled to their poverty. Yet we know that at critical historical junctures Christians can become crusaders who slaughter geopolitically dominant Muslims, Nepalese peasants can become bloodthirsty Maoists who murder landlords and underclass Colombians can form cocaine cartels that cascade violence across two continents. In all these histories, inequalities are bound up with other grievances. If we have democratic and legal institutions that genuinely listen to grievances of all kinds, and institutions of redistribution that strive to reduce inequalities of all kinds, crime and armed violence can be kept within moderate bounds. This can occur even though grievances can never be fully resolved, and even though inequalities and the power that feeds on them are so resilient that they can never be fully dissolved. What seems clear enough and evidence-based enough for those who care about domination, crime and violence is that grievance responsiveness, institutional inclusiveness and inequality reduction are the right directions for political struggle. The complexity and historical contingency of the multiplicity of grievances and levels of inequality make the struggle towards this light on the hill difficult. That is no excuse for political paralysis.

Part of the integrated social justice strategy required also involves making power accountable at all levels and tackling domination and humiliation at the level of the school, the local community, the refugee camp, the bank and at the national level and the level of global imaginaries and global 
institutions. Most importantly, these strands of a web of peace with justice must be joined up. Expressed another way, reducing inequality at the national level is part of an integrated crime-prevention and peacebuilding design that can help create an enabling environment for crime and war prevention at the local level. Quality schools and jobs near refugee camps might be more important to crime-war-suicide prevention than macronational equality; yet, without national institutions for creating good schools, good jobs and good state services for placing disadvantaged people into them, local restorative justice or peace committees cannot pull in the state welfare capabilities to realise their potential for crime-warsuicide prevention. Wherever poverty remains at the local level, wherever desperate refugees congregate, local domination will drive crime and will drive war when it connects to a more global imaginary of armed struggle against injustice.

Restorative justice that is also locally redistributive can therefore help. Peace committees that listen to stories of dominations and humiliations at all these levels and follow up on plans to ensure that domination and humiliation end can assist. Reconciliation with social justice is required at higher levels for more aggregated dominations. Reconciliation with social justice at the local level must be put in the context of local dominations and humiliations. That is why reconciliation committees in rural Pakistan, Afghanistan, Libya, Iraq and Congo are important as both peacebuilding and crime-prevention initiatives (Braithwaite and D'Costa 2018). For groups who have suffered national degradation, this aggregates to the importance of national reconciliation, reintegration and 'justice as a better future' (Froestad and Shearing 2012). Or, as Vesna Pesic's thinking about the former Yugoslavia put it, 'fear of the future, lived through the past' can motivate 'terrible evils in the present that can only be transcended by a politics of justice as a better future' (quoted in Lake and Rothchild 1998: 7). Former German Chancellor Willy Brandt illustrated the connection of justice as a better future to what criminologists call collective efficacy in projects of his political life such as his agonistic resistance to the Nazis and then apologising on his knees at the Warsaw ghetto after the event.

The best way to see the future is to influence it ... Peace like freedom is no original state which existed from the start; we shall have to make it. (Brandt 1971: 1) 


\section{Gender, domination and culturally shared values}

Applin and Messner (2015) have applied institutional anomie theory to gender and institutions. They point out that 'the economic domain is constructed as a "masculinized" space' (Applin and Messner 2015: 46). Women's values are less criminogenic because they are more institutionally tempered than those of men, who tend to be more ruthlessly committed to their individual career success. In the value framing of institutional balance, women accord a more balanced priority to the flourishing of all family members from the very young to the very old, and of all being cared for within the bosom of the family. Empirically, women give more time and priority to maintaining family infrastructure, including to ensuring that all family members flourish to their full potential through wise use of educational opportunities. Men are the ones who must change to become more like women in this regard. In many societies, women also accord more priority to community-level social capital formation and therefore contribute more to the impact of collective efficacy for crime reduction in communities, schools and families (as discussed in Chapters 7 and 11). This book has already argued that in the balance between achieving good and bad objectives by peaceful and warlike means, male values and political practices are more warlike.

Messner and Rosenfeld (2013: 91-92) summarise evidence that in the United States the American Dream is less about competitive individualism and materialism for women than it is for men. Across 84,398 individuals in 58 countries, Hövermann and Messner (2019: 17) show that men do have a more marketised mentality than women. They also point out that this observation about American society is not new, quoting Tocqueville on women's values as 'the counterweight to the pursuit of selfish interests in the marketplace' (Hövermann and Messner 2019: 423). One of the interesting contributions of Messner and Rosenfeld (2013) is their reflection on how to shift shared cultural values to make them less criminogenic. One path is to seek to feminise the values of men, to foster a culture of reflection and self-criticism among men concerning their materialism and competitive individualism. Family-level restorative justice can play a role here in asking adult men to return to listening and learning from the wisdom of elderly mothers and aunties so their families might flourish more holistically, and of course listening to their own partners and their own children on that same issue. 
An inspiring development in many Australian First Nations communities is grandmothers becoming politically organised for civil society transformation. These groups often call themselves 'the G'mars'. They insist the males of their community-as well as male political leaders of the country-listen to them in 'yarning circles'. Larissa Behrendt's award-winning film, After the Apology, shows the political and communal leadership of the G'mars and aunties in confronting the problem of a new 'Stolen Generation' of children recklessly removed from struggling Indigenous families.

Of course, there are dangers in saying to women that you are more virtuous than men in sacrificing your individual interests for the public good and the good of your family. Nondomination requires that women have as much access to individual career opportunities as men, not that women suppress their ambition. Here, institutional anomie theory needs a sharper normative grounding than it currently has. In Applin and Messner's (2015) and Messner and Rosenfeld's (2013) approach to gender politics and shared cultural values there is an incipient brilliance of insight about what is needed for the low-crime society that also has less domination. But my argument is that this promise cannot be fully realised without being clear about the value commitment to a society that maximises freedom as nondomination. ${ }^{7}$ Without clarity of normative commitment, the danger of falling into the trap of patting women on the back for making sacrifices is something for the institutional anomie theorist to explicitly resolvelikewise with the oppressed Dalit peasants in Nepal discussed above. How profound is the danger of UN peacebuilding that it might have the effect of saying to Nepalese peasants: 'For the sake of stopping the violence, please go back to not caring about the fact that the landlord class has stolen your land, deprived your children of educational opportunities, raped Dalit women and kept you in circumstances of servitude.' In some ways, UN peacebuilding, as strongly as we must support it, can say something even worse than that. All kinds of peacemaking frequently work by doing deals in which peace negotiators offer commanders of armed groups positions and perks in postwar power-sharing. The proposition is put to them that they can later use their power in the power-sharing arrangements of the new government to develop new land reforms and laws that can secure the objectives of their political movement to return to peasants land that

7 Steven Messner replied to a draft of this section that a normative vision of the good society is clear in his work with Richard Rosenfeld, which it is. This is that the good society 'facilitates the development of everyone's talents and capacities to the fullest extent possible'. 
has been stolen from them. In the event, what so often happens is that male insurgency commanders get a lot of land, but their foot soldiers from the peasantry do not (Braithwaite et al. 2012; Braithwaite and D'Costa 2018).

Whether for women, or for landless peasants, the politics of the oppressed returning to historical moderation of their aspirations risks a slippery slope to domination. For peacebuilding, there must be checks and balances that ensure independent reviews by the United Nations of whether there has been full implementation of peace agreement provisions on land rights and gender rights, or at least substantial progress. Sanctions such as UN member states holding back some foreign aid for successor states may be needed if they are not, and shifting that aid to civil society. In advance of all those implementation nuts and bolts, we must be clear about our values.

An implication of institutional anomie theory is that shared cultural values must be tempered. Cultural change is needed to temper financial objectives with the human and social capital objectives discussed in Chapter 7. The conclusion to that chapter argues that financial objectives must be tempered with environmental objectives if we are to maximise freedom as nondomination. Nondomination requires that in a rebalancing of burden-sharing towards a Green New Deal, a feminist New Deal for women and children and a better deal for the poor who miss out on material values are imperative. Sacrifice is not the right word for men who would be better off with a more feminised value-balance partly because their children and their partners will love them more, and they will enjoy being more rounded and decent. What is going on there is that making an extra million is less intrinsically rewarding than raising a beautiful child because the relationality of love for a child is more intrinsically human. Yet sacrifice is the right word when men do all the careerism and women the housework, child care and aged care. So, the feminist politics of what is required for the low-crime and low-domination society here seems very clear. It is relentless social movement and political party activism for the modulation of materialism as a cultural value. It means equality of sacrifice in the required rebalancing of culturally shared aspirations and commitments.

This political implication is more than slightly implicit in the service Applin, Messner and Rosenfeld have done in moving beyond the War on Poverty implications of opportunity theory to add that emphasis on reframing the American Dream in a feminist way. Politically and 
pragmatically, the civic republicanism of the Federalist Papers and of the next generation of constitutional debates after the Civil War (Richards 1993) seems to this outsider an inspiring font of value framing for any country. To further fuel this optimism with a more contemporary political point, there is one thing in common between the post-1968 rebelliousness of my ageing baby-boomer population against the Greatest Generation (Chapter 3) and the rebellion of the newest generation of Greta Thunberg's Generation $\mathrm{Z}$ activists. It is the spurning of materialism as the measure of success. This can be a foundation for intergenerational renewal to temper the hegemony of ruling generations by rippling social capital outwards from families and schools into economic and political institutions. This feminist take on 'extractive institutionalism' and 'limited-access orders' (that drills down to feminised family extraction, women's domination and limited access) is a strength of contemporary institutional anomie theorists more than for so many leading institutional economists and political economy thinkers. The flaws in political economy arise from the disciplinary myopia of a political science that analytically privileges state institutions and an economics that privileges market institutions to the exclusion of family institutions. Here is one site of intellectual struggle where criminology can contribute to a more institutionally plural interdisciplinarity with thanks to feminist criminology.

While this normative framing of institutional anomie theory seems clear enough, the empirics of what has happened in response to the consciousnessraising of different waves of feminism are more difficult to assess. There has been some feminist progress, with the first wave of feminism winning the vote for women, with more women in politics after the second wave, more women on corporate boards and in professional jobs than in the past. Whether these have been counterbalanced by the 'feminisation of poverty' and declining relative pay for 'feminised' professions like nursing, teaching and aged care; whether there has been little feminisation of men's values or whether there has been much masculinisation of powerful women's values - all these shifts of the historical short term may continue to be hard to assess (Applin and Messner 2015).

Patriarchy as an ideology entails men feeling humiliation at the suggestion that their partner could be equal or superior to them on as critical a dimension of male dominance as breadwinning. This is why criminologists can get Gartner and McCarthy's (1991) result that employed women married to an unemployed husband had six times the homicide victimisation one would expect given the proportion of the population 
in this group. Just as such facts complicate the direct employment-crime nexus and the patriarchy-crime nexus, they affirm the more general underlying proposition that domination engenders crime. They provoke an underlying normative vision that sets nondomination as the light on the hill for men and women.

My argument has been that a steadfast feminist politics and an intersectoral politics that embraces concern for all dominations are implications of normative-explanatory theoretical integration amid the many contingencies in the empirical effects of diverse inequalities. Hopefully, feminists would not stop being feminists if it happened to turn out that feminist politics increased crime or prolonged wars. As it happens, the empirical evidence reviewed is that feminist politics has made big contributions to crime reduction and even bigger contributions to political struggles against war (from the early days of the first wave of feminism) and to building societies that are freer. This dovetails with the feminist analysis of Chapter 3 and future chapters that concludes that in the longue durée, violence against intimate partners and rape have reduced and for the past century and a half feminist politics has been the most important contributor to this. We see the contribution from New Zealand, where women first won the national vote and where Prime Minister Jacinda Ardern today helps us see what social democratic nondomination looks like, to Nepal, where female Maoist fighters won the most feminist constitutional transformation seen so far (Braithwaite 2015).

\section{Opening blocked opportunities: Equality of freedom versus equality of opportunity}

Cloward and Ohlin wanted to see an America with less poverty and more equality of results. Their writing, however, can be criticised for playing into the diagnoses of the 'middle of the road' politics of those who believed that the only kind of War on Poverty America needed was a war on inequality of opportunity. Social democrats and socialists across the world looked upon Americas War on Poverty of the 1960s as involving no semblance of a transition of the United States to social democracy, only another version of the thin liberalism of equality of opportunity. There would be no systematic egalitarian reparations for the crimes of slavery; there would be some more points of entry for slightly expanded numbers of descendants of slaves into Ivy League universities, but nothing profoundly structural. 
It would continue to be the case that the money spent on each of the hundreds of black students at Harvard University would be less than the spending on each of a million non-white citizens still enslaved in prisons, police lockups or jails. Even Messner and Rosenfeld (2013) slightly shocked me when they approvingly cited James Q. Wilson's (1975) claim in President Gerald Ford's favourite book of the 1970s that poverty did decline in the 1960s and early 1970s, yet crime went up. What is true is that the unemployment rate almost halved between 1960 and 1969 but then, from 1969 to 1992, it almost tripled (with deindustrialisation) (Chegg Inc. 2003-21). Moreover, under the Republican administrations that were in power for most of these years, there were some significant retrenchments of the welfare state and, as Piketty (2014) showed, the tax system became much less progressive, with a top marginal income tax rate that had hit 91 per cent in the 1950s falling step by step throughout that period. Then, most fundamentally, as Piketty (2014) found, those dependent on income to pay their bills became poorer and poorer in comparison with those who lived off shares or other financial assets for some or all of their spending. It was thus not only deindustrialisation that widened the gulf between the rich and the poor, between black and white Americans, during the great crime rise from 1960 to 1992 . Piketty showed it was also the financialisation of capitalism and the capture of tax policies by the wealthy. And remember, Messner and his co-authors have shown that the regressive nature of tax systems cross-nationally is associated with higher crime rates (Piatkowska et al. 2020).

Let us concede to conservatives of the James Q. Wilson ilk who say that the War on Poverty failed. Let us concede that the not inconsiderable influence of institutional anomie theory on the War on Poverty strategy also failed. But let us be reflective on the reasons for this. The War on Poverty put only the slightest dent in the rise in poverty and inequality in the United States during deindustrialisation. Before and after the War on Poverty, the United States continued to be disengaged from the imperative for universal access to health care for all citizens, continued to have a weaker welfare state than other developed economies with lower crime rates and continued to have a more inegalitarian tax system and a more inegalitarian financialisation of capitalism than most of them. To their credit, Messner and Rosenfeld (2013: 112) do approvingly quote Ruth Sidel on why it was facile for any commentator to expect that the War on Poverty might have turned back the wave of rising American crime up to 1992: 
The War on Poverty was woefully inadequate to reverse the damage that was done, particularly to blacks, in our society: and no sooner did it get started than Vietnam, inflation, and the Nixon administration had begun to subvert it.

One misstep by Cloward and Ohlin played into the hands of conservatives like James Q. Wilson and his Republican Party fan club of the era who wilfully promoted these analytical errors. It arose from the exaggerated emphasis Cloward and Ohlin (1960:111) placed on the observation that delinquency is more likely when there is 'attribution of the cause of failure to the social order rather than oneself'. Cloward and Ohlin conjectured that the belief that failure is a result of one's personal deficiencies results in pressures to improve oneself. This leaves the legitimacy of the social order intact. One thing they saw as important in shaping whether attributions of blame were internal or external was whether they perceived systematic prejudices in conferring success, such as racial prejudice. For this reason, Cloward and Ohlin saw equality of opportunity as fundamental to reducing system-blame and therefore delinquency. Equality of opportunity could give the poor hope that they can lift themselves out of poverty, if not in this generation, then in the next. This aspect of Cloward and Ohlin's work was widely read to imply an imperative for the War on Poverty to prioritise equality of opportunity over equality of results. Braithwaite (1979-80: 92) reviewed the considerable evidence that blaming the system was not more associated with delinquency than blaming the self and the evidence that many serious offenders simultaneously blamed both the system and themselves. Subsequent work reveals even more complex intersections, such as external attribution sometimes resulting in a sense of powerlessness and learned helplessness that is then internalised (Davies and Best 1996; Davies 1997). 'Contrary to Cloward and Ohlin, it is reasonable to hypothesise that if one fails in a system, one will withdraw attributions of legitimacy to that system, irrespective of the reasons for failure' (Braithwaite 1979-80: 92). Considering all the complexity, this still seems to have correctly concluded that Cloward and Ohlin in this respect were contributing to sending the War on Poverty towards a rationale for the neglect of equality of outcomes-and that was the most important feature of its failure. Equality of opportunity is definitely important, but it is not as important for a free society as continuous struggle for more equal outcomes. Liberal interpretations of the irrelevance of the War on Poverty to solving America's problems opened the door to neoliberal excess in decentring the welfare state in crime-prevention discourse. 


\section{Conclusion}

This chapter has concluded that societies and schools that institutionalise failure and societies afflicted with a commodified and militarised vision of what success and failure mean suffer high crime rates. Messner and Rosenfeld have set criminology on a productive path towards also grappling with the role that a plurality of institutions plays in tempering the corrosive effects on crime of market institutions. The next chapter seeks to systematise what kind of pluralisation of institutional checks and balances is needed. To contemplate why this is imperative, consider Messner and Rosenfeld's thin discussion of the importance of political institutions as checks and balances on economic institutions. Operationalisation in the empirical testing of institutional anomie discussed above is even thinner. The strength of political institutions is operationalised in most studies by the percentage of voters who turn out in national elections. This is a particularly poor measure when a number of societies have compulsory voting.

Before rising to that challenge, the next chapter rises to a related challenge. In arguing that the War on Poverty in the heyday of Merton, Cloward and Ohlin and Cohen mostly failed, Messner and Rosenfeld (2013: 125-26) further opined:

We may question the effectiveness of the progressive approach to crime control for additional reasons. First, it is difficult to see how the proffered explanation of crime and the policies based on it would apply to the crimes committed by persons at the top of the opportunity structure, crimes that are far from rare and that are very costly to society.

This understates the challenge because, in Chapter 2, we have already established that crimes of the powerful cause greater property loss and greater loss of life than all other crimes combined. The next chapter seeks to rise to this challenge of elaborating institutional anomie theory to explain why societies with high inequality of wealth and power have elevated rates of crimes of the powerless and crimes of the powerful. Then it argues that if we broaden criminology's concerns from crime in the streets to crime in the suites, an even more pluralised tempering of market institutions by a rich plurality of countervailing institutions is needed. 
This text is taken from Macrocriminology and Freedom, by John Braithwaite, published 2022, The Australian National University, Canberra, Australia.

doi.org/10.22459/MF.2021.04 